\title{
Investigating the Land-Sea Transition Zone
}

\author{
Stephan Ludger Seibert, Julius Degenhardt, Janis Ahrens, \\ Anja Reckhardt, Kai Schwalfenberg, \\ and Hannelore Waska
}

\begin{abstract}
Terrestrial and marine environments merge at the land-sea transition zone. This zone is important as $\sim 38 \%$ of the world's population live by and depend on the coastal regions, and oceans are considerably affected by it. Furthermore, terrestrial and marine groundwater and seawater mix in the subterranean estuary (STE), where submarine groundwater discharge (SGD), i.e., discharging fresh groundwater and recirculated seawater, results in significant solute fluxes to the sea. With this article, we focus on advances of geochemical, microbiological, and technological aspects related to fresh groundwater, SGD, and STE in sandy coastal areas, using the barrier island Spiekeroog as a case study area. Previous studies showed that the fresh groundwater composition in sandy coastal aquifers is governed by calcareous shell dissolution, cation exchange, and organic matter degradation.
\end{abstract}

S. L. Seibert $(\varangle)$

Hydrogeology and Landscape Hydrology Group, Institute for

Biology and Environmental Sciences, Carl von Ossietzky

University of Oldenburg, Oldenburg, Germany

e-mail: stephan.seibert@uol.de

J. Degenhardt $(\square)$

Paleomicrobiology Group, Institute for Chemistry and Biology of the Marine Environment (ICBM), Carl von Ossietzky University of Oldenburg, Oldenburg, Germany

e-mail: julius.degenhardt@uol.de

J. Ahrens $\cdot$ A. Reckhardt

Microbiogeochemistry Group, Institute for Chemistry and Biology of the Marine Environment (ICBM), Carl von Ossietzky University of Oldenburg, Oldenburg, Germany

K. Schwalfenberg

Marine Sensor Systems Group, Institute for Chemistry and Biology of the Marine Environment (ICBM), Carl von Ossietzky University of Oldenburg, Wilhelmshaven, Germany

H. Waska

Research Group for Marine Geochemistry (ICBM-MPI Bridging Group), Institute for Chemistry and Biology of the Marine

Environment (ICBM), Carl von Ossietzky University of

Oldenburg, Oldenburg, Germany
Biogeochemical reactions in the STE further modify the water composition of SGD, with a dependence on residence time. Microbial communities, which are present in coastal sediments and usually follow salinity and redox gradients, are the driver for the degradation of organic matter. Regarding organic matter sources in the STE, it is evident that dissolved organic matter is primarily of marine origin and that SGD delivers degraded dissolved organic matter back into the ocean. Furthermore, recent studies used radiotracers, such as radium and radon, and seepage meters as reliable tools to quantify rates and fluxes associated with SGD. We conclude that, despite the advances being made, the complexity and interactions of the different processes at land-sea transition zones require multidisciplinary scientific approaches.

\section{Keywords}

Biogeochemistry · Freshwater lens · Marine sensors · Radiotracers · Spiekeroog Island · Submarine groundwater discharge $\cdot$ Subterranean estuary

\subsection{Introduction}

The coastal area is the interface between terrestrial and marine environments. From both environmental and (socio-)economic perspectives (Barbier et al. 2011), these are areas of enormous relevance, since $\sim 38 \%$ of the world's population lives within $100 \mathrm{~km}$ distance from the coastline (UNEP 2014). In environmental sciences, the importance of this landsea transition zone arises from a number of processes: (i) Land-sea interactions significantly affect global ocean material inventories due to export of terrestrially derived compounds to the ocean (Jeandel and Oelkers 2015); (ii) extensive land use and growing populations in coastal areas have a high impact on coastal ecosystems and aquifers, for example, high population densities in coastal areas present a risk for fresh- 
water resources as well as for coastal ecosystems due to overexploitation, potentially leading to saltwater intrusion, and the disposal of waste and release of contaminants (Post 2005); and (iii) climate change and rising sea levels affect the coastal areas disproportionally relative to their size, giving them the description as the "frontlines of climate change" (Barbier 2015). For instance, it is expected that rising sea levels will increase land loss, storm intensities, floodings, and saltwater intrusion in coastal areas (e.g., McGranahan et al. 2007; Werner and Simmons 2009; Nicholls and Cazenave 2010). Continental fluxes to the ocean include riverine and atmospheric inputs, as well as submarine groundwater discharge (SGD). SGD was defined as "[...] any and all flow of water on continental margins from the seabed to the coastal ocean [...]" by Burnett et al. (2003) and comprises terrestrial groundwater as well as recirculated seawater. The great importance of SGD has become widely accepted with emerging applications of radiotracer balances, and it could be demonstrated that SGD contributes significant fluxes of nutrients (Hays and Ullman 2007; Tait et al. 2014) and metals (Basu et al. 2001; Windom et al. 2006) to coastal oceans. In some cases, groundwater-derived nutrient and metal inputs may even rival river inputs (Moore 1996). The zone where terrestrial groundwater and seawater mix was consequently termed "subterranean estuary" (STE, Moore 1999) and shown to be a hot spot of biogeochemical reactions, further affecting the composition of SGD (Charette and Sholkovitz 2002; Roy et al. 2011; McAllister et al. 2015).

The objective of this article is to give an overview of recent advances made in scientific fields related to the land-sea transition zone, with a focus on STE and SGD in sandy coastal areas. Sandy beaches are an important part of the global land-sea transition zone, as they account for one third of the world's icefree coastline (Luijendijk et al. 2018). Furthermore, the high permeability of sandy beach sediments permits advective pore water flow and allows for efficient transport of water constituents, resulting in steep environmental gradients and dynamic interfaces (Huettel et al. 1998; Riedel et al. 2010). We use the barrier island Spiekeroog located in the Southern North Sea, Germany, as a case study area in some of the following sections. Spiekeroog Island is characterized by mesotidal sandy beaches impacted by strong hydro-morphodynamic variations (Flemming and Davis 1994) and steep pore water salinity gradients due to the evolution of freshwater lenses below the dune areas. Therefore, Spiekeroog Island presents an excellent study site for the investigation of land-sea transition zones, SGD, and chemical reactions in sandy coastal STE.

As the freshwater composition is not only critical for drinking water supply in coastal areas but also for the chemical processes happening in the STE, the evolution of coastal freshwater aquifers is reviewed in Sect. 12.2, using freshwater lenses below (barrier) islands as an example. The effect of biogeochemical processes, including microbially mediated redox processes, and salinity gradients on the pore water chemistry of sandy STE is examined in Sect. 12.3. Moreover, the role and sources of labile organic matter, which fuels sedimentary redox processes in sandy STE, is reviewed in Sect. 12.4. Here, we focus on the concentration and reactivity of individual (dissolved) organic compounds controlling the rate and efficiency of organic matter degradation in the STE. Furthermore, the composition of microbial communities in tidal sands and their ability to utilize different electron donors and acceptors are explored with respect to the biogeochemical processes in, and signature of, sandy STE in Sect. 12.5. As biological processes often are kinetically driven, water infiltration rates and residence times are of great relevance for the chemical composition of pore waters and constituent transport in the STE and, thus, for the efficiency of the biogeochemical reactor (Anschutz et al. 2009; Tamborski et al. 2017). The presence of natural radioisotopes, such as radium $(\mathrm{Ra})$ and radon $(\mathrm{Rn})$ isotopes, provides the basis for determining groundwater residence times and quantifying SGD, which is reviewed in Sect. 12.6. Lastly, substantial progress in sensor technologies has been made since the discovery of SGD. Today, new methods based on the state-ofthe-art sensor technologies can produce continuous datasets, which allow for detailed insights into physicochemical processes at the land-sea transition zone and provide a basis for modeling approaches, as examined in Sect. 12.7.

\subsection{The Hydrochemical Evolution of Coastal Fresh Groundwater: Using Barrier Island Freshwater Lenses as an Example}

Coastal freshwater aquifers are important for the land-sea transition zone, as fresh groundwater eventually discharges into the subterranean estuary (STE) and finally the ocean (e.g., Burnett et al. 2003; Röper et al. 2015). Here, the freshwater chemistry is of importance for further biogeochemical reactions and potentially plays a significant role for fluxes of nutrients and reduced species (Moore 1999, 2010; Slomp and Van Cappellen 2004; Spiteri et al. 2008). Freshwater lenses (FWL) on barrier islands present a special case of coastal freshwater aquifers and allow for hydrochemical investigations of groundwater at the land-sea transition zone. This section provides an overview of advances which were made regarding the hydrochemical evolution of FWL, as an example for coastal freshwater aquifers.

FWL on barrier islands evolve in dune areas that are not prone to inundation events (Röper et al. 2013; Holt et al. 2017). The formation process is mainly driven by density differences between infiltrating freshwater and saline groundwater (Drabbe and Badon Ghijben 1889; Herzberg 1901; Fetter 1972; Vacher 1988), while factors such as tides, 
groundwater recharge rates, land propagation, or climate change may play an additional role (Röper et al. 2013; Stuyfzand 2017; Holt et al. 2019). Being the only natural freshwater resource on barrier islands, FWL are precious for both drinking water supply and freshwater ecosystems. However, storm surges, sea level rise, and overexploitation pose serious threats to these sensitive aquifers (Anderson 2002; Post 2005; Post and Houben 2017).

A major process that determines the water composition of FWL below barrier islands is the dissolution of calcareous shell debris (Röper et al. 2012; Houben et al. 2014; Seibert et al. 2018; Fig. 12.1a). Shell dissolution results from the infiltration of acidic rain into dune sediments, with further acidity being supplied to the subsurface due to carbon dioxide production from respiration in the soil by vegetation and microorganisms (Stuyfzand 1993, 1998). Marine shells, including those in the North Sea region, are predominantly made up of biogenic carbonates (e.g., Blackmon and Todd 1959; Hild 1997; Milliman et al. 2012; Seibert et al. 2018; Winde and Böttcher, unpubl. data), and the dissolution of these typically leads to an enrichment of bicarbonate and calcium in FWL (e.g., Röper et al. 2012; Houben et al. 2014). The dissolution of calcite may take place in the waterunsaturated zone, i.e., an open system with respect to a $\mathrm{CO}_{2}$ bearing gas phase, or in the water-saturated zone, i.e., a closed system (Appelo and Postma 2005). To distinguish between open or closed system conditions during calcite dissolution and to study further carbonate mineral reactions within the aquifer, carbon isotopes are widely used as an additional tool to bicarbonate and calcium concentrations

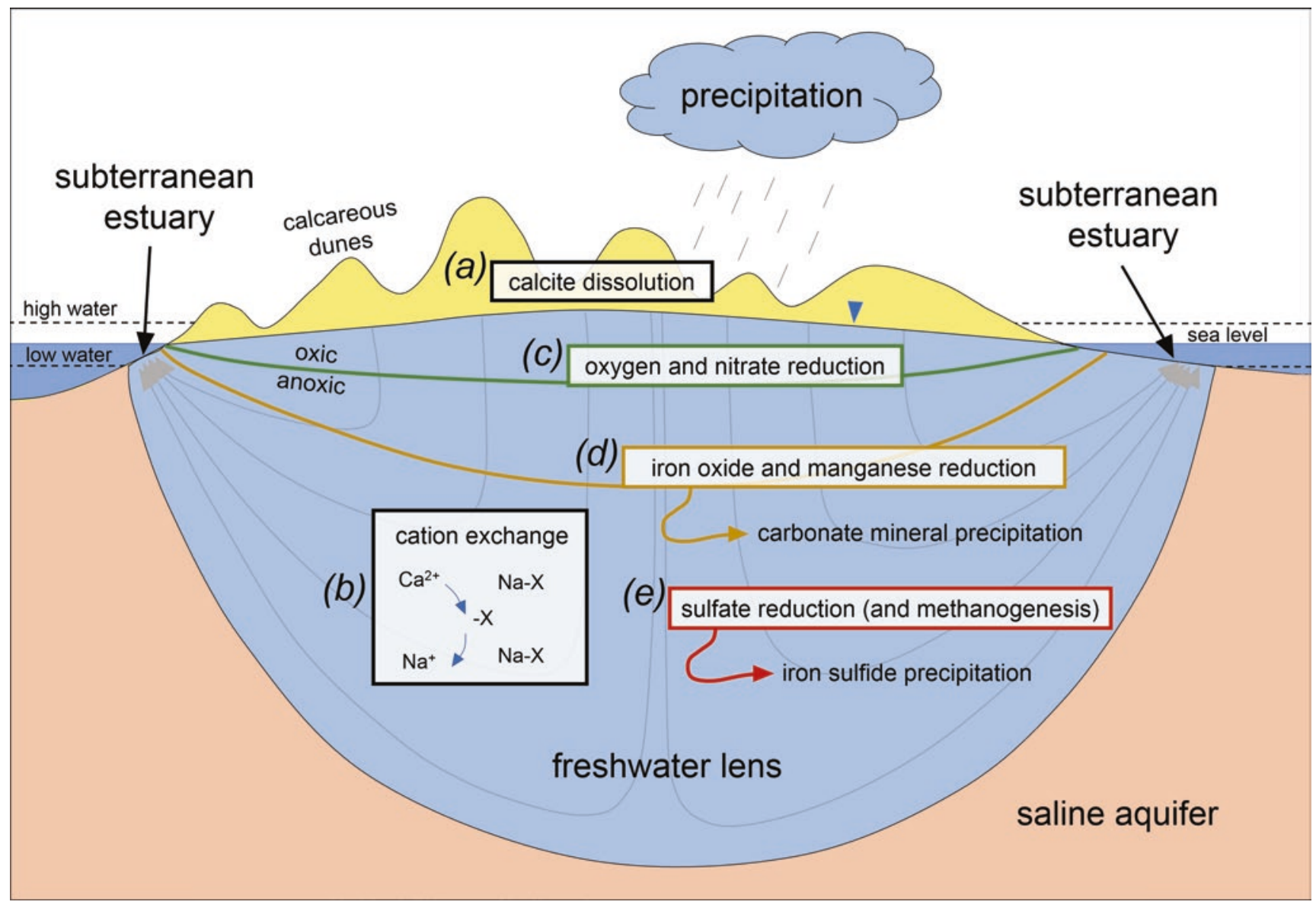

Fig. 12.1 Conceptual model of a freshwater lens below a barrier island and important hydrogeochemical processes. The hydrologic cycle of the freshwater lens starts with precipitation infiltrating into the dune sediments, followed by groundwater recharge, flow through the freshwater lens (conceptual flowlines are indicated), and discharge in the STE. (a) calcite dissolution, typically proceeding in the unsaturated dune sediments, (b) cation exchange in a freshening aquifer, and (c) to (e) redox processes related to the degradation of organic matter, i.e., zones of oxygen and nitrate reduction (green colors), iron and manganese oxide reduction (brown colors), and sulfate reduction as well as methanogenesis (red colors), respectively, are indicated. (d) brown and (e) red arrows highlight that reduced species (i.e., $\mathrm{Fe}^{2+}, \mathrm{Mn}^{2+}$, and $\mathrm{H}_{2} \mathrm{~S}$ ) may precipitate as carbonate minerals (e.g., siderite and rhodochrosite) and iron sulfides, respectively, in the anoxic zone of the freshwater lens. Note that the figure is not to scale. The vertical freshwater lens extent is exaggerated in comparison to the horizontal extent. Typically, horizontal and vertical extents of FWL below barrier islands range between several meters to kilometers and several meters to tens of meters, respectively 
(Deines et al. 1974; Chapelle and Knobel 1985; Böttcher 1999). This is applicable because ${ }^{13} \mathrm{C}$ signatures of dissolved inorganic carbon (DIC) produced in the unsaturated zone are a function of the ${ }^{13} \mathrm{C}$ signature of the soil $\mathrm{CO}_{2}$ gas phase and the $\mathrm{pH}$, while the ${ }^{13} \mathrm{C}$ signature of DIC produced in the saturated zone is a function of both the signature of the dissolved, acidity-providing $\mathrm{CO}_{2}$ and the dissolving carbonate (Deines et al. 1974; Appelo and Postma 2005). With regard to FWL, Bryan et al. (2017) and Seibert et al. (2018) used ${ }^{13} \mathrm{C}$ signatures of DIC to identify carbonate recrystallization processes within the aquifer. By applying ${ }^{13} \mathrm{C}$ signatures of DIC, Seibert et al. (2018) could further infer that degrading organic matter in the investigated unsaturated dune sediments presumably had a terrestrial origin.

Cation exchange is another prominent process at the landsea transition zone. The governing principle is that the exchange of cations along a flow path is retarded compared to the pore water velocity, depending on the aquifer cation exchange capacity (CEC) and the composition of the initial (e.g., saline groundwater) and the infiltrating solutions (e.g., fresh groundwater) (Appelo and Geirnaert 1991; Stuyfzand 1993, 1999; Appelo and Postma 2005). Aquifer freshening accompanied by cation exchange is a commonly observed process in coastal aquifers and proceeds via the exchange of dissolved calcium (the dominant cation in freshwater of calcareous aquifers) for sodium, potassium, and magnesium (the dominant cations in seawater) bound to the aquifer solid phase (Fig. 12.1b) until equilibrium with fresh groundwater is reached (Appelo and Postma 2005). Therefore, a simultaneous decrease of calcium and an increase of sodium, potassium, and magnesium are typically observed along the flow path of a freshening aquifer (Chapelle and Knobel 1983; Beekman and Appelo 1991; Appelo and Postma 2005). For the case of evolving FWL below barrier islands, previous studies have shown that water compositions usually reflect the above-described trends for major ions in a freshening aquifer (Röper et al. 2012; Houben et al. 2014; Seibert et al. 2018). Cation exchange can further trigger calcite dissolution in a freshening aquifer due to the removal of solute calcium, subsequently leading to a subsaturation with respect to calcite. This was, for example, observed by Andersen et al. (2005) for a coastal sand aquifer prone to storm floodings, and Seibert et al. (2018) found indications for calcite dissolution triggered by cation exchange in a FWL of Spiekeroog Island, which was especially relevant at the early stages of the lens formation. Freshening times of FWL below sandy barrier islands typically range between several hundreds and thousands of years, after a hydrodynamic steady-state has been reached. As an example, Seibert et al. (2018) calculated a total freshening time of $\sim 600$ years for the freshwater aquifer below Spiekeroog Island, Germany. Freshening times may, however, greatly vary depending on aquifer properties (e.g., CEC), recharge rates, and end-member compositions.
The water composition of FWL below barrier islands is further modified by the degradation of organic matter via the consumption of different electron acceptors (Fig. 12.1c-e). Following the classical redox cascade based on overall energy yields and competitive exclusion, oxygen is consumed first followed by nitrate, manganese and iron oxide, and sulfate reduction and methanogenesis (e.g., Lovley and Phillips 1987; Chapelle and Lovley 1992; Appelo and Postma 2005), and reduced species (e.g., ammonium, sulfide, ferrous iron) are released to the groundwater under increasingly anoxic conditions. However, the redox sequences may not be as strictly separated in nature, because zones of iron oxide and sulfate reduction and methanogenesis can overlap, with a dependence on organic matter reactivity, iron oxide stability, and sulfate concentrations (Postma and Jakobsen 1996; Jakobsen and Postma 1999). While oxic to metal oxide reducing conditions were reported for near-surface groundwater of a FWL below a barrier island in Georgia, USA, by Snyder et al. (2004) and oxic conditions for a FWL in a limestone aquifer at Rottnest Island, Australia, by Bryan et al. (2017), Seibert et al. (2018) could show that also sulfate reduction and localized methanogenesis can be important pathways for the decomposition of organic matter in deeper and older groundwater of a barrier island FWL. The reduced species which are produced under anoxic conditions, such as dissolved ferrous iron and sulfide, may further undergo secondary reactions (Fig. 12.1d, e). For instance, dissolved sulfide may precipitate as iron sulfide (e.g., mackinawite and/or pyrite) if reactive iron oxides are present (Schoonen 2004; Rickard and Morse 2005), which was observed for the brackish transition zone of a young FWL at Spiekeroog Island (Seibert et al. 2019). Manganese and ferrous iron may precipitate as metal carbonates (e.g., rhodochrosite and siderite) if hydrochemical conditions are favorable (e.g., Seibert et al. 2018).

In conclusion, previous research has shown that the hydrochemical evolution of FWL in sandy calcareous barrier islands is dominated by calcite dissolution, typically leading to increased bicarbonate and calcium concentrations in young groundwater. Furthermore, cation exchange can affect the groundwater cation composition, with sodium and calcium concentrations commonly increasing and decreasing, respectively, along the flow path in a freshening aquifer. Finally, redox processes related to the oxidation of organic matter result in the consumption of different electron acceptors and the release of reduced species to the groundwater, which may cause secondary reactions such as the precipitation of iron sulfides or metal carbonates. Fresh submarine groundwater discharge (SGD) at barrier islands may, thus, supply anoxic groundwater (iron oxide- to sulfate-(methanogenic-)reducing conditions) to the STE with elevated concentrations of nutrients from degrading organic 
matter (e.g., ammonium and phosphate) and further reduced species, such as dissolved sulfide. Although the governing processes for the evolution of fresh groundwater in sandy coastal aquifers could be identified, future research could benefit from the following motivations: (i) Fresh groundwater end-member compositions should be better characterized to evaluate the role of fresh SGD for the chemical processes occurring in the STE and to quantify material fluxes from land to ocean; (ii) the effect of changing boundary conditions (e.g., changing amounts of groundwater recharge, variations of anthropogenic pollution inputs, effects of groundwater pumping and/or inundation events) as well as local effects (e.g., heterogeneities of the geology, effect of different vegetation covers) should be regarded; (iii) reaction rates are often not well-constrained and should be investigated more closely by combining field studies with reactive transport modeling; and (iv) hydrochemical and geochemical studies should be jointly conducted where possible to link aquifer solute and solid-phase biogeochemistry.

\subsection{Nutrients and Trace Metals in Subterranean Estuaries of Sandy Beach Sediments}

The nutrient and trace metal distribution in the pore water of subterranean estuaries (STE) is strongly affected by salinity and redox gradients. Under reducing conditions, nitrogen may be lost through denitrification. Manganese and iron oxide reduction lead to the liberation of dissolved manganese and iron to the pore water and the subsequent release of phosphorus from the solid phase (Stal et al. 1996; Slomp and Malschaert 1997). Sulfate-reducing conditions result in the precipitation of iron as iron sulfide (Roy et al. 2011). The aeration of surface sediments, in turn, may lead to nitrification and the precipitation of manganese and iron oxides, the latter resulting in the removal of phosphate through adsorption (Slomp and Malschaert 1997; Spiteri et al. 2008). Increased pore water silica concentrations may result from the dissolution of biogenic opal, e.g., diatom frustules, or quartz dissolution (Anschutz et al. 2009; Ehlert et al. 2016).

Wave- and tide-dominated sandy beaches typically exhibit a salinity distribution being characterized by a surficial saline circulation cell in the intertidal zone. A freshwater discharge tube separates this upper saline plume from the saltwater wedge near the low water line (Robinson et al. 2007). The saline circulation cell may have a vertical extent of more than 15 meters (Robinson et al. 2007; Seidel et al. 2015; Beck et al. 2017). Low-salinity water discharging at the low water line has traveled a long way to its discharge point (Fig. 12.1) and may thus have a different redox state and nutrient and trace metal composition compared to young low-salinity groundwater found in the supratidal area of a beach site (Reckhardt et al. 2017). Seawater circulating through the beach face is usually also subject to changing redox conditions with increasing residence time in the sediment, i.e., along the flow path toward the low water line (O’Connor et al. 2015; Reckhardt et al. 2015).

On Spiekeroog Island (Germany), groundwater of the island's freshwater lens mixes with a small portion of seawater close to the dunes (Fig. 12.2). This pore water is characterized by high nitrate concentrations indicating oxic conditions. Around the mean high water level, oxic seawater infiltrates into the sediment. However, aerobic degradation of organic material is limited to the upper 1-2 m. Below, nitrate serves as terminal electron acceptor, and low concentrations of nitrite are found in the pore water. Toward the low water line, the oxic sediment layer stretches only some centimeters, whereas anoxic conditions and reduction of iron, manganese, and occasionally sulfate are found below (Fig. 12.2). This part close to the discharge point is characterized by high nutrient (dissolved inorganic carbon, ammonium, phosphate, and silica) and metal (manganese and iron) concentrations. Freshwater infiltration from below decreases the salinity near the low water line (Fig. 12.2). According to a modeling approach, this water originates from deep $(>20 \mathrm{~m})$ and anoxic parts of the island's freshwater lens (Beck et al. 2017; compare Fig. 12.1). This freshwater lens is characterized by low dissolved iron and manganese concentrations (Seibert et al. 2018).

In contrast, there are other STE where fresh groundwater is a significant iron and manganese source. These systems are typically characterized by metal oxide precipitation, where suboxic freshwater encounters oxic seawater (Charette et al. 2005; McAllister et al. 2015). A second source of manganese and iron may develop in the saline circulation cell. Such conditions were found in the STE of Waquoit Bay, Massachusetts, USA (Charette et al. 2005). Under sulfidic conditions, however, iron may be removed from the solution due to the precipitation of iron sulfides (McAllister et al. 2015).

At the Aquitanian coast (France), the saline circulation cell of the intertidal zone is also characterized by decreasing oxygen concentrations toward the discharge point. Redox conditions, however, do not reach a lower level than occasional denitrification, and the main nitrogen species being discharged remains to be nitrate, not ammonium (Charbonnier et al. 2013). Similarly, at Huntington Beach (California, USA), oxic freshwater meets oxic saline pore water, and nitrogen discharges primarily as nitrate. Low organic matter inputs and high advective pore water flow allow the groundwater pool of such systems to remain oxygenated (Santoro 2009).

Several studies suggest that pore water draining from sandy coastal sediments represents a source of nutrients and 


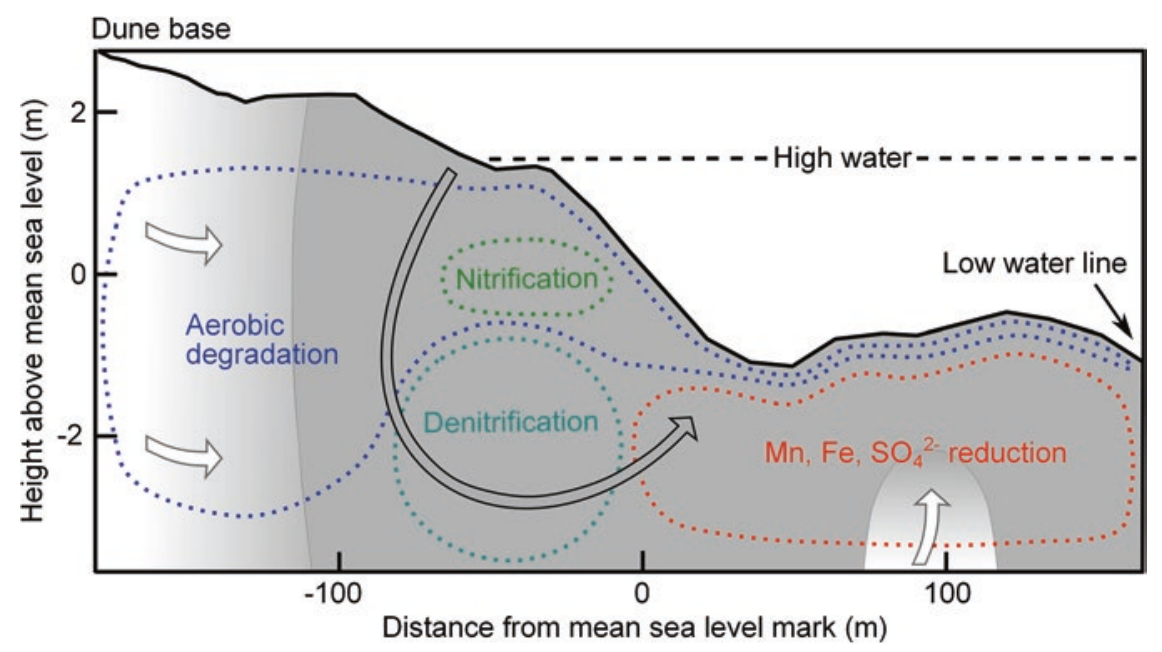

Fig. 12.2 Biogeochemical processes and redox zones at a beach site studied on Spiekeroog Island (based on the concept of Beck et al. 2017). The transect stretches from close to the dune base to the low water line. Aerobic degradation (blue) dominates close to the dune base, nitrification (green) and denitrification (cyan) were identified at the high water line and $\mathrm{Mn} / \mathrm{Fe}$ oxide and sulfate reduction (red) take

Table 12.1 Nutrient fluxes from subterranean estuaries into adjacent seawater

\begin{tabular}{l|l|l}
\hline Nutrient & Flux $\left(\mathrm{mmol} \mathrm{d}^{-1} \mathrm{~m}_{\text {shoreline }}{ }^{-1}\right)$ & Reference \\
\hline $\mathrm{NO}_{3}{ }^{-}$ & 296 & Anschutz et al. (2009) \\
\hline $\mathrm{NH}_{4}{ }^{+}$ & 117 & Beck et al. (2017) \\
\hline $\mathrm{PO}_{4}{ }^{3-}$ & 55 & Beck et al. (2017) \\
\cline { 2 - 3 } & 15.2 & Anschutz et al. (2009) \\
\hline $\mathrm{Si}(\mathrm{OH})_{4}$ & 575 & Beck et al. (2017) \\
\hline $\mathrm{Mn}$ & 48 & Reckhardt et al. (2017) \\
\hline $\mathrm{Fe}$ & 185 & Reckhardt et al. (2017) \\
\hline
\end{tabular}

trace metals to the surrounding surface seawater (Caetano et al. 1997; Kroeger and Charette 2008; Anschutz et al. 2009). This flux can be in the order of millimoles per day and meter of shoreline (Table 12.1). The examples listed above show that STE can be subject to different redox characteristics, which have a major influence on the pore water composition. Since organic matter degradation occurs in most STE, nutrient concentrations are higher in pore waters compared to adjacent seawater at many locations. Where aerobic degradation dominates, the beach may serve as source of dissolved inorganic carbon, nitrate, phosphate, and silica to the surrounding ocean. Under anaerobic conditions, manganese and iron may be added to the nutrient pool and nitrogen will be discharged as ammonium. STE may consequently play different roles in coastal carbon, nutrient, and trace metal cycling (Slomp and Van Cappellen 2004). Therefore, it is necessary to characterize redox conditions in many beach systems and to quantify solute fluxes into the adjacent ocean to finally be able to assess the global impact of SGD. over toward the low water line. The shading indicates the gradient from fresh terrestrial groundwater (white) to saline seawater (gray). The arrows show main groundwater flow pathways, such as the upper saline plume (gray arrow) and terrestrial freshwater input from the island's freshwater lens and freshwater discharge tube (white arrows)

\subsection{Dissolved Organic Matter in the Subterranean Estuary}

Dissolved organic matter (DOM), operationally defined as any organic matter passing through a $0.2-0.7 \mu \mathrm{m}$ filter, is the fuel that drives microbial respiration and production of the climate-relevant carbon dioxide in the subterranean estuary (STE). It is therefore a crucial link between the organic and inorganic carbon cycle at this land-ocean interface. Dissolved organic matter can be quantified as dissolved organic carbon (DOC), but DOM compounds may also contain hydrogen, oxygen, nitrogen, phosphorous, and sulfur. Furthermore, they can bind and transport trace metals in coordination complexes. Early quantitative investigations of bulk DOC in a STE showed conservative increases with increasing salinities, leading to the suggestion that DOC was not substantially altered on its passage through the coastal aquifer (Beck et al. 2007). However, Santos et al. (2008, 2009) found enrichment of DOC at mid-salinities compared to the lowand high-salinity end-members in the STE, analogous to surface estuaries (Osterholz et al. 2016). They attributed this pattern to microbial release of DOC from marine debris buried during tidal inundation, as well as autochthonous production, for example, by microphytobenthos (Santos et al. 2008, 2009; Chipman et al. 2010; Reckhardt et al. 2015). Despite reporting contrasting patterns in DOC distributions within the STE, studies on DOC indicated three overarching trends: (i) The majority of the DOC loads were derived from autochthonous and allochthonous marine sources, (ii) the marinederived DOC drives microbial respiration successions (oxygen respiration, denitrification, and iron and manganese 
reduction) along the groundwater flow paths, and (iii) the tide- and wave-driven burial and hydrolysis of marine organic matter may turn terrestrial, fresh groundwater or brackish groundwater mixtures into transport vehicles for marine DOM (Santos et al. 2008, 2009; Reckhardt et al. 2015; Beck et al. 2017). As a consequence of the dominance of marine DOC in the STE, the resulting submarine groundwater discharge (SGD) delivers mainly recycled DOC back into the coastal water column. The input of this recycled DOC is particularly high during summer, when primary production in the water column and activity of the STE microbial reactor are highest (Santos et al. 2009; Kim et al. 2012).

DOC is merely a bulk proxy for DOM, containing no qualitative information about sources and reactivity of its components. Taking elemental combinations, size fractions, and steric properties into account, it is likely that DOM consists of hundreds of thousands of individual compounds at the pico- to nanomolar level (Zark et al. 2017). Fluorescence and absorbance analyses of chromophoric DOM (CDOM) provide swift and straightforward identification of organic compound groups with chemical characteristics indicative of their reactivity and origin (Coble 1996). These analyses can be combined with targeted measurements of molecular building blocks, for example, sugars and amino acids, as well as bulk determinations of $\delta^{13} \mathrm{C}$ isotope signatures characteristic for terrestrial and marine primary producers. The most comprehensive method of DOM characterization to date is ultrahigh resolution Fourier transform ion cyclotron resonance mass spectrometry (FT-ICR-MS), which allows the assignment of unique molecular formulae to thousands of masses detected in a single DOM sample (Fig. 12.3).

So far, only two publications report FT-ICR-MS data of DOM composition in the STE (Seidel et al. 2015; Beck et al. 2017), whereas CDOM analyses are more widely applied (Kim et al. 2012, 2013; Suryaputra et al. 2015; Nelson et al. 2015; Couturier et al. 2016). Overall, these qualitative DOM studies confirmed supply of marine, labile DOM to the STE by tides and waves, indicated by enrichment patterns of labile organic matter, such as sugars, amino acids, and protein-like CDOM, at deposition sites of algal debris or in areas where seawater infiltration occurred (Fig. 12.3; Kim et al. 2012; Seidel et al. 2015). On the other hand, strong negative correlations of humic-like CDOM fluorescence and absorbance with salinity have been attributed to a terrestrial source of aromatic DOM compounds. As a result, humic-like CDOM fluorescence has been used as SGD tracer in areas with productive submarine springs (Fig. 12.3; Nelson et al. 2015; Kim and Kim 2017). Compared to aliphatic, proteinlike CDOM, the aromatic, humic-like DOM compounds are less biodegradable and more photodegradable and absorb sunlight. Furthermore, humic-like DOM compounds form complexes with trace metals such as iron and copper, and iron oxide formation along redox gradients of the STE has been identified to sequester terrestrially derived organic matter (Abualhaija et al. 2015; Linkhorst et al. 2017; Sirois et al. 2018). This means that the quality of DOM in STE could vary substantially along the advective flow paths, with profound effects on DOM bioavailability, reactivity, and light attenuation of the receiving coastal water column.

Although overarching patterns of DOM processing in several STE have been derived from quantitative and qualitative studies, still surprisingly little is known about this important electron donor which drives the microbial reactor (see also Sect. 12.5) and is thus crucial in controlling retention and/or release of, for example, inorganic nutrients (nitrogen, phosphorous, and carbon dioxide) and redox-sensitive trace metals (manganese, iron). Export of organic matter from the STE into the coastal water column could be an important land-ocean pathway affecting the global carbon budget. However, to date even quantitative DOC data are only available for a handful of sites, although SGD is a ubiquitously occurring phenomenon along the global coastline (Zhang and Mandal 2012). While the first global estimates on SGDdriven nitrogen, phosphorous, and silicon fluxes have been published recently (Cho et al. 2018), not enough data exists to calculate potential contributions of SGD to land-ocean DOC inputs. Furthermore, qualitative data are still lacking for a larger diversity of STE. These data are imperative, however, to delineate recycled marine inputs from new terrestrial loads, which are likely to increase as a result of global climate change (higher temperatures and precipitation). Finally, ultrahigh resolution molecular data will be crucial to assess the information gathered by swift in situ methods such as CDOM tracing. For example, Suryaputra et al. (2015) found release of humic-like fluorescent DOM (FDOM) at midsalinities in a STE and linked these signals to marine rather than terrestrial sources. This may prevent an unambiguous identification of DOM sources based on CDOM data alone. A fundamental understanding of DOM behavior throughout the STE is an essential prerequisite to develop mechanistic models for geochemical speciation, which currently neglect DOM complexity. Such adapted reactive transport models will ultimately be the key to predict the role of SGD as DOC source or sink in the light of global change.

\subsection{Microbial Community Composition of the Subterranean Estuary}

From a microbiological perspective, land-sea interfaces are of special interest, since end-members with different nutrient compositions and physicochemical parameters merge. These environmental settings are known to enhance microbial diversity by creating niches for specialists. Coastal seawater usually is rich in sulfate, oxygen, and organic carbon, but (temporarily) limited in nitrogen, while terrestrial ground- 


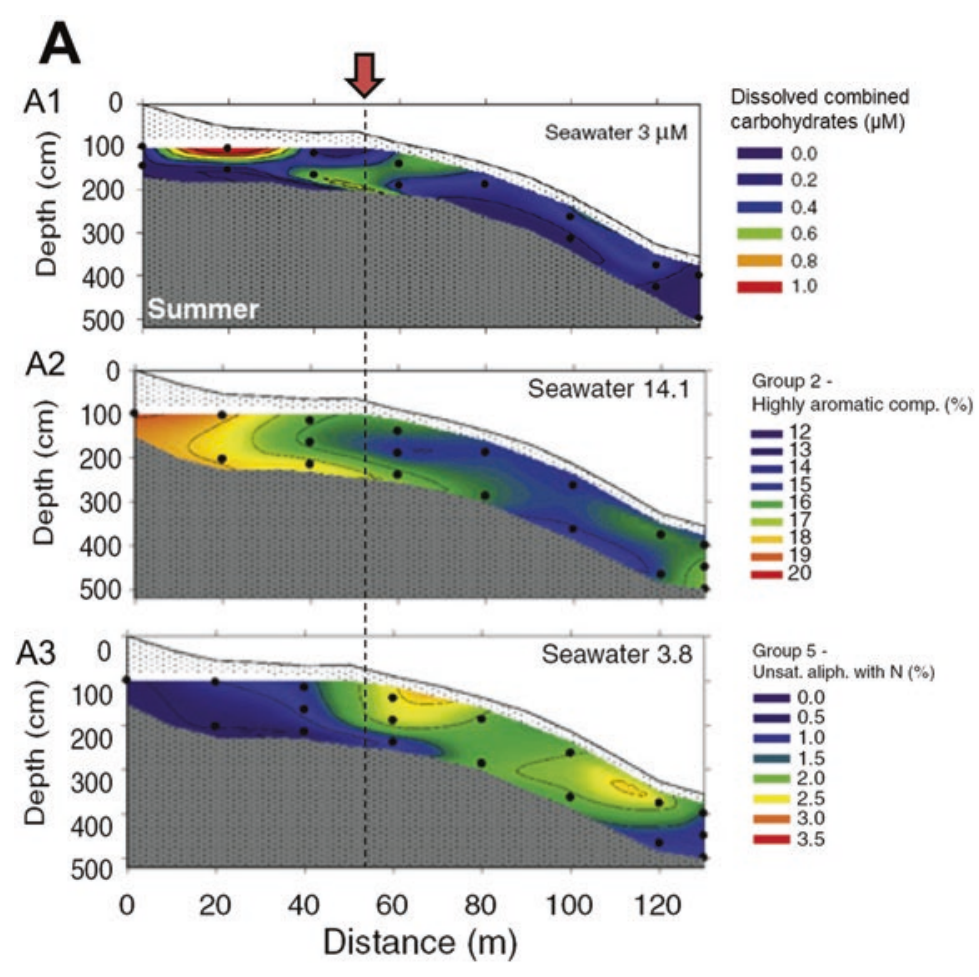

B
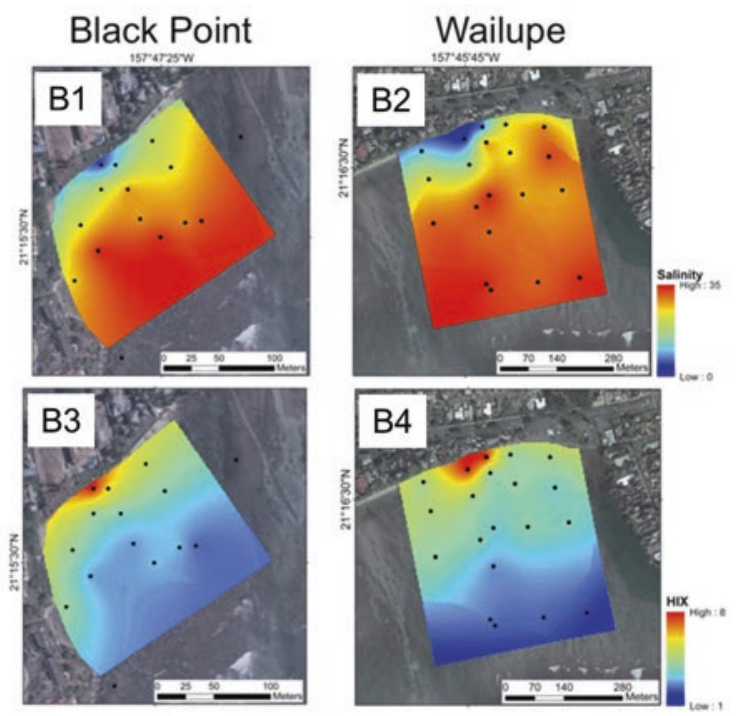

Fig. 12.3 (a) Distribution of carbohydrates (a1, concentration in $\mu \mathrm{M})$ and DOM molecular groups indicative of terrestrial (aromatic compounds, $\mathbf{a} 2$, relative abundance in \%) and marine (aliphatic peptide formula compounds, a3, relative abundance in \%) origin in a STE on Spiekeroog Island during a summer campaign. The $\mathrm{x}$ axis shows distance in $(\mathrm{m})$ from the dune base toward the low water line, and the $y$ axis shows sampling depths in $(\mathrm{cm})$. The red arrow indicates the mean high water line. White dotted areas represent de-saturated sediments,

water often can be a source of nitrogen, phosphorous, and iron. Garcés et al. (2011) have previously shown that nutrient input by terrestrial sources can influence microbial abundance and diversity and even induce phytoplankton blooms.

In coastal systems, the sedimentation of decaying phytoplankton blooms stimulates the activity of heterotrophic bacteria by introducing large quantities of organic carbon. The high microbial activity leads to a rapid depletion of electron acceptors like oxygen and nitrogen, usually in the form of nitrate. In Wadden Sea tidal-flat sediments, which are mostly sand flats, this typically happens within the first millimeters to centimeters (Billerbeck et al. 2006; Böttcher et al. 2000). Following a thin zone of manganese and iron reduction, those sediments then show wide zones of sulfate reduction and methanogenesis (Wilms et al. 2007). A similar pattern, following the availability of electron acceptors, has been reported for other land-sea transition zones, e.g., for mangrove systems (Kristensen et al. 2000; Holguin et al. 2001), yet these environments are different from sandy beaches in many of their physicochemical characteristics. Furthermore, submarine groundwater discharge (SGD), which can transport nutrient quantities comparable for which no pore water could be extracted, and grey areas indicate the water-saturated, unsampled deep sediment layer. (b) Co-variance of low salinity groundwater springs $(\mathbf{b} 1, \mathbf{b} 2)$ and humic-like CDOM (represented by the "HIX" index, b3, b4) in two marine embayments, Black Point and Wailupe, on Hawaii. Low salinities are indicated by cool colors, and high relative abundances of terrestrially-derived humic substances (or HIX) are indicated by warm colors. Modified from (a) Seidel et al. (2015) and (b) Nelson et al. (2015) with permissions from Elsevier

to those of rivers (Kwon et al. 2014), influences microbial communities and biogeochemical cycling in the subterranean estuary (STE).

The solute composition of pore water being transported into the ocean is altered along the flow path due to the reduction of electron acceptors and the oxidation of organic matter by microbial communities (Slomp and Van Cappellen 2004). On the one hand, the way of alteration depends on the community composition of the STE. On the other hand, the microbial communities and thus their metabolic potential are influenced by the physicochemical properties (e.g., salinity, temperature) within the STE (Santoro et al. 2008; Lee et al. 2016). Understanding which microbes are driving specific biogeochemical cycles in the STE and the respective conditions that are necessary for them to thrive in this habitat will help to predict the effects of SGD on different coastal environments. So far, only little is known about microbial communities in STE at the land-sea transition zone and the key processes they are driving. Most studies on these kinds of aquifers were performed from a chemical point of view (Santos et al. 2008) but are lacking a molecular in-depth analysis on the microbial communities. 
Furthermore, not many studies have looked at the microbial diversity of STE, using modern sequencing technologies. A previous molecular study from the island of Spiekeroog by Beck et al. (2017) was based on denaturing gradient gel electrophoresis (DGGE). However, DGGE is an early molecular technique and does not gain the detailed amount of information like next-generation sequencing. Despite the technological limitations, the authors found a higher diversity of the bacterial communities in comparison to those of the archaea, which confirms findings of Lipp et al. (2008). They also showed that aerobic organic matter degradation dominates the supratidal part of the beach, while suboxic and anoxic processes like manganese and iron reduction become dominant in sediments located closer to the low water line (Figs. 12.1 and 12.2). Sulfate reduction seems to be insignificant in the first $1.5 \mathrm{~m}$ of the investigated sediments. A similar microbial response was assumed by a geochemical study on salt marshes of Sapelo Island, Georgia, USA (Snyder et al. 2004). Here, iron reduction was identified as the main pathway of anaerobic organic matter degradation, despite the availability of sulfate. This finding is surprising, since if the investigated sediments are not very oligotrophic, metal oxides are usually reduced quickly, followed by sulfate reduction in deeper sediment layers. Yet none of those two studies could show why metal oxide reduction is preferred over sulfate reduction and which bacteria are involved in this process. A study conducted by McAllister et al. (2015) at Cape shores, Lewes, Delaware, USA, describes an iron-rich aquifer with a distinct zone characterized by iron sulfides at the discharge site, which precipitate due to active sulfate reduction. Within that aquifer, the microbial community is structured along the availability of different iron and sulfur species, and not only sulfate reduction but also iron oxidation was observed in different parts of the aquifer.

However, microbial community compositions are not only shaped by the availability of electron acceptors but also by the physicochemical properties of the investigated systems (Santoro et al. 2008; Lee et al. 2016). Santoro et al. (2008) investigated a sandy STE at Huntington Beach, California, USA, with a focus on the abundances of ammonium-oxidizing proteobacteria and ammoniumoxidizing archaea. While the archaea showed constant abundances independent of the salinity, abundances of bacterial ammonium oxidizers were much lower under freshwater than under saltwater conditions. They also observed that the shift between those two groups migrated with the brackish mixing zone during the year. Another study that found a correlation between microbial community structure and hydrology was performed at Jeju Island, Korea, by Lee et al. (2016), who discovered that the microbial community composition can be altered by the SGD rate within the different stages of a tidal cycle.
In summary, it is not yet coherently understood which microbial groups thrive in STE, how the geochemical conditions are shaping the community composition, and what hydrogeological factors are introduced by the heterogeneity of land-sea interfaces. Microbial diversity and activity are not only influenced by the availability of different electron acceptors and donors but also by hydrological parameters influencing the stability of redox conditions and salinities, such as waves, SGD discharge rate, and seasonal patterns. In order to understand if and how microbial processes influence coastal oceans by changing the chemical composition within STE, further in-depth research is needed to determine key species responsible for organic matter degradation and nutrient cycling. For instance, while SGD with an anthropogenic influence contributes to coastal ocean eutrophication (Beusen et al. 2013), the effect of SGD in pristine areas is fully unclear. Investigating this would give an understanding of how the chemical load transported within a STE is altered before being discharged into the oceans. Another question to be answered is which factors are responsible for the occurrence of sulfate reduction in STE, as it proceeds to a significant degree at some locations, while it cannot be detected at others.

\subsection{Radiotracers: A Useful Toolbox for Quantifying Rates and Fluxes}

\subsubsection{Estimating Pore Water Residence Times}

A key factor governing organic matter degradation efficiency and nutrient transformation pathways within subterranean estuaries (STE) is the pore water residence time, which is defined as the timespan between seawater infiltration and discharge. Numerical simulations showed that seawater residence times can range from orders of a few days in the upper saline plume to about 1000 days in the saltwater wedge (Robinson et al. 2007). The combination of residence times and microbial reaction rates determines nutrient and metal transformations as well as organic matter degradation efficiency. After oxygen has been consumed, other electron acceptors are favored, lowering the redox potential and affecting nitrogen transformation: As an example, short residence times (up to 1 week) in combination with a large supply of oxygen may enrich pore waters in nitrate by nitrifying organic bound nitrogen (Anschutz et al. 2009). Contrary, at a certain setup of residence times and hydrogeological forcing, denitrification can remove nitrate efficiently by producing $\mathrm{N}_{2}$ (Heiss et al. 2017). Finally, long residence times in the range of months can lead to an enrichment in ammonium, enhancing the overall export of dissolved inorganic nitrogen (Beck et al. 2017; Tamborski et al. 2017). The residence time may therefore have profound influence on the release of degrada- 


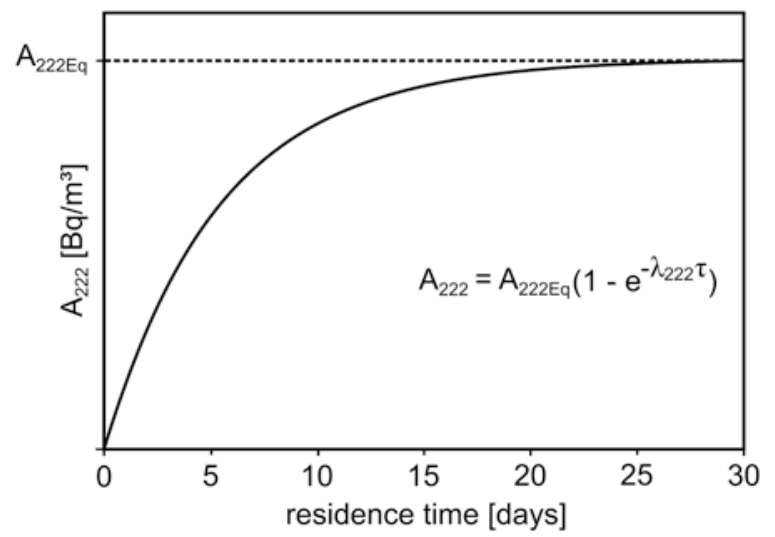

Fig. 12.4 Activity of dissolved ${ }^{222} \mathrm{Rn}\left(\mathrm{A}_{222}\right)$ as function of $\mathrm{A}_{222 \mathrm{Eq}}$ and $\lambda_{222}=0.1813$ day $^{-1}$

tion products like nutrients, metals, and inorganic carbon into the pore water and finally to the adjacent sea.

To estimate pore water residence times, the usage of dissolved ${ }^{222} \mathrm{Rn}$ (half-life of 3.8 days) has become a valuable method in both marine and terrestrial systems (Hoehn and Von Gunten 1989; Snow and Spalding 1997; Colbert et al. 2008; Goodridge and Melack 2014; Tamborski et al. 2017). In seawater, ${ }^{222} \mathrm{Rn}$ activities ${ }^{1}$ are low due to its decay, degassing, and a high rate of dilution of pore water-derived ${ }^{222} \mathrm{Rn}$. This results in the initial ${ }^{222} \mathrm{Rn}$ activity of infiltrating seawater to be almost zero. Within the sediment, dissolved ${ }^{222} \mathrm{Rn}$ is produced by the decay of its parent isotope ${ }^{226} \mathrm{Ra}$, which is part of the uranium decay chain and occurs naturally in sediment minerals and in Fe-Mn oxide coatings on mineral surfaces (Swarzenski 2007). Because of the long half-life of the parent isotope ${ }^{226} \mathrm{Ra}$ (1602 years), its own decrease is negligible and the production rate of ${ }^{222} \mathrm{Rn}$ remains constant. After a certain time of increasing ${ }^{222} \mathrm{Rn}$ activity, it reaches an equilibrium activity $A_{222 E q}$ (Fig. 12.4), and the production of ${ }^{222} \mathrm{Rn}$ is balanced by its own decay. Since the absolute decay rate of ${ }^{222} \mathrm{Rn}$ is proportional to its concentration, a certain level of ${ }^{222} \mathrm{Rn}$ has to grow in until its production rate is balanced. The calculation of residence times is based on the predictable ingrowth of ${ }^{222} \mathrm{Rn}$ until the equilibrium activity $A_{222 E q}$ is reached (after 5-6 half-lives, or 20-25 days; Fig. 12.4). Because the half-life of ${ }^{222} \mathrm{Rn}$ (3.8 days) is much shorter than of ${ }^{226} \mathrm{Ra}$ (1602 years), it can be assumed that under equilibrium the ${ }^{222} \mathrm{Rn}$ activity equals its precursor's activity - in other terms, whenever a ${ }^{226} \mathrm{Ra}$ atom disintegrates, its daughter isotope ${ }^{222} \mathrm{Rn}$ is "immediately" decaying (Eq. 12.1):

$$
A_{226} \approx A_{222 E q}
$$

Based on the assumption of a constant production rate, the Bateman equation (Bateman 1910), describing activities in decay chains, can be transformed to describe the temporal

${ }^{1}$ Radioactive compounds are typically expressed quantitatively by their activity (a combination of concentration and decay constant). evolution of the ${ }^{222} \mathrm{Rn}$ activity $A_{222}$. Thus, $A_{222}$ is a function of its production rate, which is equal to $A_{222 E q}$ and its own decay rate $\lambda_{222}=0.1813$ day $^{-1}$ (Eq. 12.2, Fig. 12.4):

$$
A_{222}=A_{222 E q}\left(1-e^{-\lambda_{222} \tau}\right)
$$

If $A_{222 E q}$ is known, the equation can easily be solved for residence time $\tau$. Tamborski et al. (2017) additionally corrected for initially dissolved seawater ${ }^{222} \mathrm{Rn}$ and extended the equation to eliminate excess ${ }^{222} \mathrm{Rn}$ deriving from mixing with deep fresh groundwater, potentially delivering high loads of ${ }^{222} \mathrm{Rn}$ to the STE.

The application of this equation requires the boundary conditions of a closed system and the assumption that ${ }^{226} \mathrm{Ra}$ is equally distributed in the sediment. Because the ingrowth of ${ }^{222} \mathrm{Rn}$ approaches its equilibrium activity asymptotically (Fig. 12.4), the application is limited to a maximum residence time of four to five half-lives (15-20 days). While early studies investigated ${ }^{222} \mathrm{Rn}$ residence times in terrestrial aquatic systems (Hoehn and Von Gunten 1989; Snow and Spalding 1997), Colbert et al. (2008) used ${ }^{222} \mathrm{Rn}$ to deduce flow dynamics in a tidal beach. The authors assessed the potential of $\mathrm{Rn}$ as a geochronometer by comparing ${ }^{222} \mathrm{Rn}$ residence times with residence times derived from tidal wedge balance calculations of the same site. However, the authors considered Rn loss due to evasion to unsaturated sediments as a reason of age underestimations. In tidal systems with significant water table fluctuations, the characteristics of ${ }^{222} \mathrm{Rn}$ as dissolved gas need to be considered.

A detailed study of applying ${ }^{222} \mathrm{Rn}$ and $\mathrm{Ra}$ isotopes as indicators of seawater residence times in a tidal STE was published by Tamborski et al. (2017). The authors compared two sites and could deduce the influence of different hydrological forcing regimes on residence times of circulating seawater: A large seaward hydraulic gradient of fresh groundwater leads to short residence times of infiltrating seawater in the intertidal circulation cell, whereas longer seawater residence times were observed at a site, where freshwater supply was reduced and seawater percolation dominated the flow regime. Additionally, by investigating sediment geochemistry, the radionuclide behavior was linked to $\mathrm{Fe}$ and Mn cycles, as their oxyhydroxides may scavenge Ra. Due to the microbially mediated dissolution of its carrier phase, a redistribution of ${ }^{226} \mathrm{Ra}$ may change the production rate of ${ }^{222} \mathrm{Rn}$ (Tamborski et al. 2017). This is offending the necessary condition of a constant ${ }^{222} \mathrm{Rn}$ production rate, respectively, equilibrium activity $A_{222 E q}$ (Eq. 12.2), creating uncertainties and restricting its applicability.

The studies listed above demonstrate that Rn disequilibrium approaches are a promising method in dynamic beach systems. Permeable sandy beaches are often fulfilling the requirements for ${ }^{222} \mathrm{Rn}$ applications, with respect to timescales and flow velocities. The knowledge about temporal hydrodynamics in beach systems is vital to understand the 
pathways and the efficiency of organic matter degradation and biogeochemical rates in groundwater.

\subsubsection{Quantification of Submarine Groundwater Discharge}

The importance of processes in the STE derives from the fluxes of ecologically relevant pore water constituents across the sediment water interface (Marsh Jr 1977; Moore 1996; Kim et al. 2005). Estimating these fluxes is challenging, because it requires the volumetric quantification of submarine groundwater discharge (SGD). Groundwater seepage is spatially and temporally highly variable and has been observed to occur patchy, diffuse, and variable on different timescales (seconds to seasons), depending on aquifer characteristics and driving forces (Burnett et al. 2006; Santos et al. 2012). Various methods have been developed and applied to quantify SGD: For example, a very simple method to quantify discharge includes the use of manual seepage meters - usually PVC or steel domes, which collect the discharging water in a plastic bag to measure its volume (Fig. 12.6). However, if SGD is assumed to have a patchy distribution, several seepage meters of this kind would be necessary to quantify SGD accurately (Burnett et al. 2006). Numerical modeling approaches are much more complex and can also be applied to calculate volumetric fluxes. In general, numerical models are calibrated, using field data to estimate, for instance, hydraulic conductivities, the unconfined storage coefficient, and to reproduce observed salinity distributions (e.g., Beck et al. 2017). The main challenge is to obtain these input variables representatively, because these may vary in space and time (Burnett et al. 2006). Numerical modeling requires a set of assumptions, boundary conditions, and simplifications. Hence, simple modeling approaches are not capable to capture aquifer heterogeneities sufficiently, leading to errors or limitations in SGD estimates.

Another option to estimate groundwater fluxes is to use natural radiotracers, which are highly enriched in groundwater relative to seawater and behave conservatively with respect to mixing and biological processes (Moore 1996). Unlike residence time calculations (cf. Sec. 12.6.1), which focus on the radioisotope behavior in the sediment subsurface prior to discharge, groundwater flux quantifications rely on the behavior of radioisotopes in the water column after discharge.

The application of Ra isotopes and ${ }^{222} \mathrm{Rn}$ has evolved to a well-established method to estimate groundwater input (Burnett and Dulaiova 2003; Kim et al. 2005; Burnett et al. 2006; Moore 2006; Peterson et al. 2008; Liu et al. 2018). The advantage of using a natural tracer approach is that it integrates overall groundwater input pathways and is not affected by small-scale spatial heterogeneities or temporal variations
(Burnett et al. 2006). The disadvantage of these methods is that calculations are based on isotope mass balances that require the knowledge of all sinks and sources, which are often challenging to determine (Burnett et al. 2006).

The principle of SGD calculation is based on a steadystate mass balance approach: The tracer's addition to a box (e.g., shelf water volume) is balanced by its loss including decay, mixing loss, and atmospheric evasion for the gaseous Rn (Fig. 12.5) (Burnett and Dulaiova 2003). Therefore, all non-SGD sources must be quantified, such as diffusion from sediments and river flux in case of Ra applications - often estimated by determining background activities. Additionally, exchange at the box edges (mixing loss) and residence time of water within that box must be well constrained (Burnett and Dulaiova 2003). Another prerequisite is that the endmember activity of SGD is known, which is still the most struggling step, and contributes to large proportions of uncertainties of that approach (Burnett and Dulaiova 2003; Burnett et al. 2006; Peterson et al. 2008).

In a detailed study, applying $\mathrm{Rn}$ and $\mathrm{Ra}$ isotopes, Peterson et al. (2008) determined an offshore transport rate, to better constrain the offshore mixing loss factor. The authors calculated apparent water mass ages on an offshore transect using the activity ratio of short-lived ${ }^{224} \mathrm{Ra} \quad\left(A_{\text {Ra22 }}\right.$; $\lambda_{224}=0.1909$ day $\left.^{-1}\right)$ to long-lived ${ }^{223} \mathrm{Ra} \quad\left(A_{\text {Ra223 }}\right.$; $\lambda_{223}=0.0606$ day $\left.^{-1}\right)$ :

$$
A R=\frac{A_{R a 224}}{A_{\text {Ra 223 }}}
$$

Based on the assumption that the same activity ratio is constantly discharging into the water column by SGD, the temporal evolution of this ratio can be predicted due to their distinct half-lives. Consequently, the timespan from being discharged $\left(A R_{\text {initial }}\right)$ to reaching its sampling site $\left(A R_{\text {observed }}\right)$ can be calculated (Moore 2000):

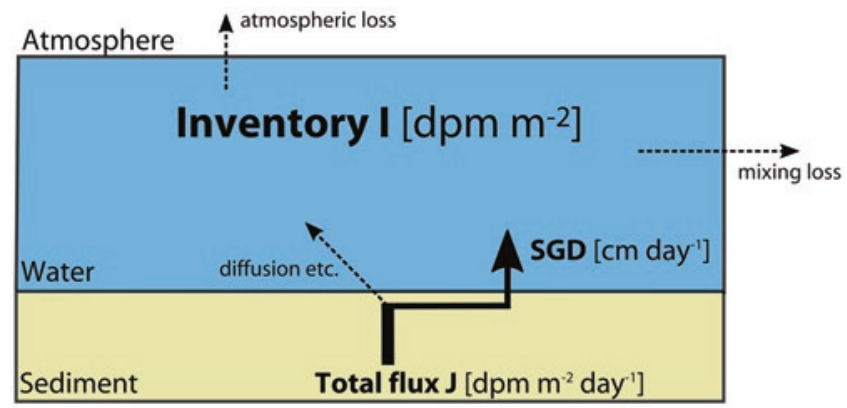

Fig. 12.5 Conceptual model of the radon ( $\mathrm{Rn})$ mass balance. Submarine groundwater discharge (SGD) and diffusion are supplying $\mathrm{Rn}$, whereas mixing loss and atmospheric loss reduce the inventory of $\mathrm{Rn}$ in a defined volume. All non-SGD sources and sinks, which need to be well-constrained, are indicated by dashed lines. The figure was produced based on the concept of Burnett and Dulaiova (2003) 


$$
t=\ln \left(\frac{A R_{\text {initial }}}{A R_{\text {observed }}}\right) \frac{1}{\lambda_{224}-\lambda_{223}}
$$

$A R_{\text {initial }}$ corresponds to the end-member concentration measured at seepage sites. Peterson et al. (2008) combined the transport rate, based on the water age calculation, and a $24 \mathrm{~h}$ time series sampling to calculate SGD rates in the Yellow River Delta, China. They found nitrate fluxes from SGD were two- to threefold higher compared to river fluxes to the adjacent sea. This often overlooked nutrient input mechanism can be a missing term in coastal nutrient budgets and, at worst, support the growth of harmful algal blooms (Hu et al. 2006).

Numerous studies have applied $\mathrm{Ra}$ isotopes and ${ }^{222} \mathrm{Rn}$ methods to calculate SGD contributions of pore water constituents to coastal waters - often conducted in bays which simplify the declaration of box boundaries (see listed in Burnett et al. 2006; Liu et al. 2018). The comparison of different SGD quantification methods has shown that each method addresses SGD in a specific way, and a combination of methods is the best way to constrain SGD in a comprehensive way (Burnett et al. 2006). Because Ra isotopes are preferentially desorbed from particles by water with high ionic strength ( $\mathrm{Li}$ et al. 1977), estimations based on $\mathrm{Ra}$ isotopes are affected by the saline component of SGD. In contrast ${ }^{222} \mathrm{Rn}$ is not affected by pore water salinity and generally captures total SGD. The subtraction of both flux estimations could thus account for the fresh SGD component (Mulligan and Charette 2006; Peterson et al. 2008).

It is vital to understand the transformation and liberation of nutrients, carbon, and metals in the STE to determine the fate of pore water constituents at the land-sea interface. Residence time calculations can help to constrain these mechanisms. Additionally, gaining knowledge about the magnitude of SGD-derived inputs is essential to understand coastal (eco-)systems. Ra isotopes and ${ }^{222} \mathrm{Rn}$ are extremely useful tracers of SGD, and adapting their chemical behaviors and half-lives to the study site and the timescales of SGD flow paths will help to constrain hydrodynamic driving factors and their influence in the coastal realm.

\subsection{Developing a New Type of Seepage Meter}

For a better understanding of the role of submarine groundwater discharge (SGD) for solute fluxes and coastal environments, it is necessary to determine the flow rates and the physical parameters of discharge. The flow rate seems to vary during tidal cycles in direction and intensity, and, thereby, also the physical parameters, e.g., electrical conductivity or temperature, may change. To get a better understanding of temporal and spatial

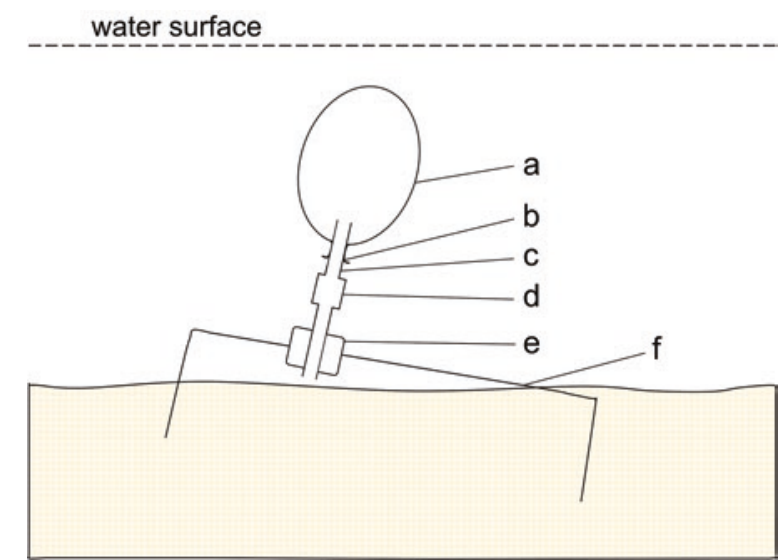

Fig. 12.6 Concept of the seepage meter based on Lee (1978), which is properly placed in the sediment. (a) 4 liter plastic bag; (b) rubber-band wrap; (c) polyethylene tube; (d) amber-latex tube; (e) one hole rubber stopper; (f) epoxycoated cylinder

patterns of SGD in sandy subterranean estuaries (STE), high temporal resolution measurements during several tidal cycles are needed.

A common device for measuring SGD is a seepage meter, built as a dome with an attached bag on top (Fig. 12.6). The dome collects outflowing groundwater and transfers it into the bag (Lee 1977, 1978). With this approach, it is possible to get an integrated signal for a defined area over a given time, yielding a flow rate. One disadvantage of this method is that the measurement time is limited due to the volume of the bag. Other seepage meter models are, for example, equipped with an ultrasonic sensor (Paulsen et al. 2001) or with an electromagnetic sensor (Rosenberry and Morin 2004; Waldrop and Swarzenski 2006) for measuring water flow of SGD. These models need a direct connection to a base station and an onshore power supply.

A study on SGD on Spiekeroog Island, Germany, shows that outflow rates are relatively low (between 2 and $\left.4 \mathrm{l} \mathrm{m}^{-2} \mathrm{~h}^{-1}\right)$, and, due to this, it is difficult to accurately measure volumes (Grünenbaum et al. 2017). Furthermore, to obtain high-resolution measurements of the outflow without any influence of the mechanical measurement systems, it is necessary to measure the flow without direct contact. Therefore, a new generation of seepage meters is currently being developed (Fig. 12.7). This new type of seepage meter is equipped with sensors for several physical parameters. It operates autonomously with a battery pack and without a pumping system or mechanical applications, which would disturb the natural water flow. Two sensor systems are installed in the seepage meter: firstly, the RBRmaestro CTD (RBR Ltd., Canada) with sensors for conductivity, temperature, pressure, fluorescent dissolved organic matter (fDOM) (420 nm), turbidity, dissolved oxygen, and $\mathrm{pH}$ and, secondly, a FEH521 flow meter (ABB Ltd., Switzerland) for the flow rates in both directions (Figs. 12.7 and 12.8). The advantage 
Fig. 12.7 Field application of the new type of seepage meter. The black box in the middle of the picture is the measurement chamber, containing the sensors inside. The control unit and the battery pack for the flow meter can be seen on the right side. Photography by K. Schwalfenberg

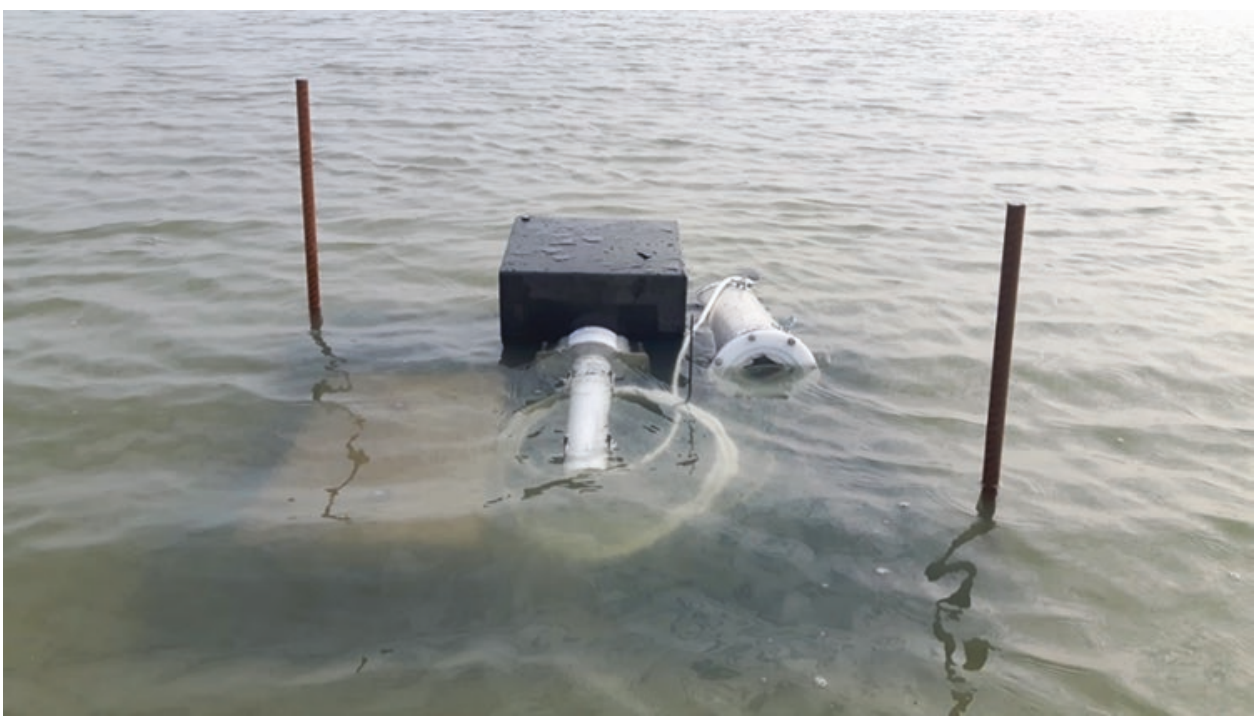

Fig. 12.8 Conceptual set-up of the new type of seepage meter. Blue arrow $=$ flow direction of the groundwater outflow, 1 = EM flow meter, $2=$ RBRmaestro

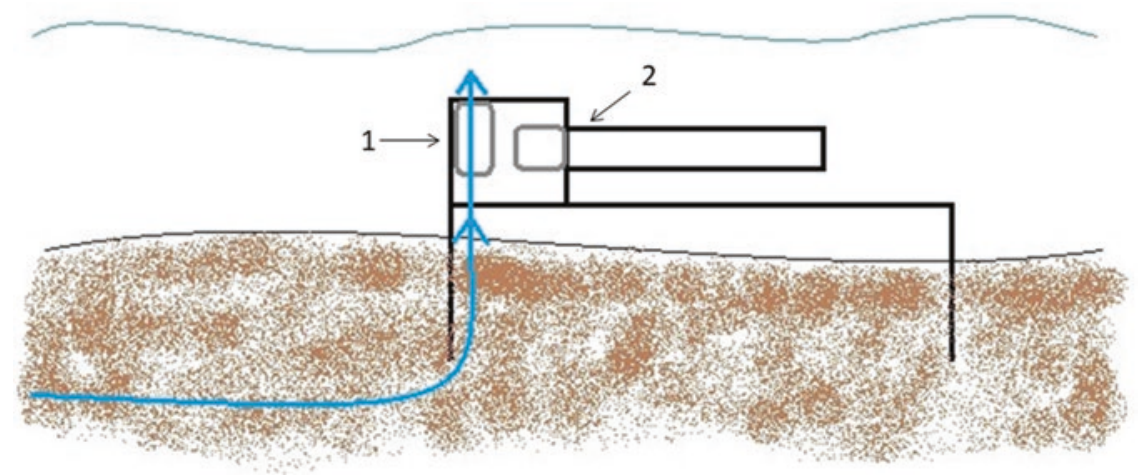

of the flow meter is that flow rates are measured in both directions with an electromagnetic field without disturbing the natural water flow.

First measurements show that the principle of the new type of seepage meter works well. After installation at the low water line at the Northern beach on Spiekeroog Island, the physicochemical parameters collected with the RBRmaestro sensor system indicate influence of terrestrial groundwater, i.e., fresh SGD. While the seepage meter is filled with pure seawater at the beginning directly after deploying at the low water line, the data demonstrates exchange of seawater by SGD after one tidal cycle. Our preliminary results show that conductivity and temperature are the most reliable parameters for a direct differentiation of the different water bodies (i.e., terrestrial groundwater, seawater, or a mixture of both). In combination with pressure data, we could infer whether groundwater exfiltrates or seawater infiltrates. The new type of seepage meter is, however, still in the process of development, with the flow meter sensor, control unit, and battery pack facing some issues related to the application underwater.

\subsection{Outlook}

The land-sea transition zone includes the subterranean estuary (STE), the zone where terrestrial fresh and marine saline groundwater as well as seawater mix. Sandy beaches are examples of land-sea transition zones. They are characterized by, among other things, steep physicochemical gradients manifested in salinity, inorganic chemistry, availability and characteristics of organic matter, microbial community composition, and flow regimes.

To better understand the environmental processes and complex system interactions at the land-sea transition zone, previous studies as well as our research activities at Spiekeroog Island have demonstrated that a broad scientific approach is needed. For instance, hydrogeologic studies are necessary to determine relevant hydrochemical processes, such as decalcification, cation exchange, and organic carbon remineralization, and to characterize the composition of freshwater that discharges into the STE. This will in part influence the biogeochemical processes occurring in pore waters and sediments of the STE, which ultimately govern the chemistry of submarine groundwater discharge (SGD). 
The characterization of (dissolved) organic matter further is crucial to determine its origin and reactivity and to identify possible transformation processes. This is necessary to, for example, explain spatial trends of microbial respiration or to estimate the role of SGD for marine carbon budgets. As microbial communities are vital for most biogeochemical processes, a detailed investigation of microbial communities at different locations (e.g., marine, terrestrial, varying flow/ discharge rates) and along biogeochemical gradients is required to link observed biogeochemical patterns to microbial activity. This will, for example, help to explain local signatures of the STE and improve our understanding regarding the microbiogeochemistry of natural sediments. Ultimately, measures of pore water residence times and SGD are needed to estimate and predict, for instance, rates of organic matter oxidation/transformations and constituent fluxes from the STE into the adjacent coastal ocean. As described above, natural radiotracers, such as $\mathrm{Rn}$, can be successfully applied to determine pore water residence times and characterize SGD. Although recent studies on SGD benefit from advances in technology, high temporal and spatial variability can still cause large uncertainties, particularly when upscaling local fluxes to estimate the global imprint of SGD. The improvements of marine sensor systems are promising to more accurately (e.g., higher temporal resolution, increasing number of measurable parameters) quantify and characterize SGD.

While this review article only focuses on some aspects of the land-sea transition zone including hydrochemistry, microbiogeochemistry, tracer-based flux estimations, and marine sensor systems, it is clear that a multidisciplinary research approach is the key to disentangling the complexity and understanding the interrelations of the environmental processes in coastal areas. Besides the reviewed fields, multidisciplinary approaches may extend to further disciplines, such as biology (e.g., McLachlan 1983; Charbonnier et al. 2016), geophysics (e.g., Swarzenski et al. 2007; Stieglitz et al. 2008; Dimova et al. 2012), or social sciences (e.g., Defeo et al. 2009; Jones et al. 2007).

Acknowledgments The authors wish to thank B. Engelen, G. Massmann, and B. Schnetger for support during the writing process. H. Nicolai, G. Behrens, M. Friebe and H. Simon are thanked for their manifold support during field campaigns and lab work. Moreover, the authors are very thankful to the YOUMARES organization team, namely, V. Liebich and S. Jungblut. We would further like to thank M.-L. Paulsen and one anonymous reviewer for their very constructive comments, which helped us to improve the quality of the manuscript. The German Research Foundation (DFG, project number MA 3274/6-1, BR 775/33-1) and the Niedersächsisches Ministerium für Wissenschaft und Kultur (MWK) in the scope of project "BIME" (ZN3184) are thanked for project funding.

\section{Appendix}

This article is related to the YOUMARES 9 conference session no. 15: "Investigating the land-sea transition zone." The original Call for Abstracts and the abstracts of the presentations within this session can be found in the Appendix "Conference Sessions and Abstracts", Chapter "12 Investigating the Land-Sea Transition Zone", of this book.

\section{References}

Abualhaija MM, Whitby H, van den Berg CM (2015) Competition between copper and iron for humic ligands in estuarine waters. Mar Chem 172:46-56

Andersen MS, Nyvang V, Jakobsen R et al (2005) Geochemical processes and solute transport at the seawater/freshwater interface of a sandy aquifer. Geochim Cosmochim Acta 69(16):3979-3994

Anderson WP Jr (2002) Aquifer salinization from storm overwash. J Coast Res 18(3):413-420

Anschutz P, Smith T, Mouret A et al (2009) Tidal sands as biogeochemical reactors. Estuar Coast Shelf Sci 84:84-90

Appelo CAJ, Geirnaert W (1991) Processes accompanying the intrusion of salt water. Hydrogeology of salt water intrusion. A selection of SWIM papers. Int Contr Hydrogeol 11:291-303

Appelo CAJ, Postma D (2005) Geochemistry, groundwater and pollution, 2nd edn. CRC Press/Taylor \& Francis Group, Amsterdam

Barbier EB (2015) Climate change impacts on rural poverty in lowelevation coastal zones. Estuar Coast Shelf Sci 165:A1-A13

Barbier EB, Hacker SD, Kennedy C et al (2011) The value of estuarine and coastal ecosystem services. Ecol Monogr 81(2):169-193

Basu AR, Jacobsen SB, Poreda RJ et al (2001) Large groundwater strontium flux to the oceans from the Bengal Basin and the marine strontium isotope record. Science 293(5534):1470-1473

Bateman H (1910) Solution of a system of differential equations occurring in the theory of radioactive transformations. Proc Camb Philos Soc $15: 423-427$

Beck AJ, Tsukamoto Y, Tovar-Sanchez A et al (2007) Importance of geochemical transformations in determining submarine groundwater discharge-derived trace metal and nutrient fluxes. Appl Geochem 22:477-490

Beck M, Reckhardt A, Amelsberg J et al (2017) The drivers of biogeochemistry in beach ecosystems: a cross-shore transect from the dunes to the low-water line. Mar Chem 190:35-50

Beekman HE, Appelo CAJ (1991) Ion chromatography of fresh-and salt-water displacement: laboratory experiments and multicomponent transport modelling. J Contam Hydrol 7(1-2):21-37

Beusen AHW, Slomp CP, Bouwman AF (2013) Global land-ocean linkage: direct inputs of nitrogen to coastal waters via submarine groundwater discharge. Environ Res Lett 8(3):034035

Billerbeck M, Werner U, Bosselmann K et al (2006) Nutrient release from an exposed intertidal sand flat. Mar Ecol Prog Ser 316:35-51. https://doi.org/10.3354/meps316035

Blackmon PD, Todd R (1959) Mineralogy of some foraminifera as related to their classification and ecology. J Paleontol 33(1):1-15 
Böttcher ME (1999) The stable isotopic geochemistry of the sulfur and carbon cycles in a modern karst environment. Isot Environ Health Stud 35(1-2):39-61

Böttcher ME, Hespenheide B, Llobet-Brossa E et al (2000) The biogeochemistry, stable isotope geochemistry, and microbial community structure of a temperate intertidal mudflat: an integrated study. Cont Shelf Res 20:1749-1769. https://doi.org/10.1016/ S0278-4343(00)00046-7

Bryan E, Meredith KT, Baker A et al (2017) Carbon dynamics in a late quaternary-age coastal limestone aquifer system undergoing saltwater intrusion. Sci Total Environ 607:771-785

Burnett WC, Dulaiova H (2003) Estimating the dynamics of groundwater input into the coastal zone via continuous radon-222 measurements. J Environ Radioact 69:1-2

Burnett WC, Bokuniewicz H, Huettel M et al (2003) Groundwater and pore water inputs to the coastal zone. Biogeochemistry 66:3-33

Burnett WC, Aggarwal PK, Aureli A et al (2006) Quantifying submarine groundwater discharge in the coastal zone via multiple methods. Sci Total Environ 367:498-543

Caetano M, Falcão M, Vale C et al (1997) Tidal flushing of ammonium, iron and manganese from inter-tidal sediment pore waters. Mar Chem 58:203-211

Chapelle FH, Knobel LL (1983) Aqueous geochemistry and the exchangeable cation composition of glauconite in the Aquia aquifer, Maryland. Groundwater 21(3):343-352

Chapelle FH, Knobel LL (1985) Stable carbon isotopes of $\mathrm{HCO}_{3}$ in the Aquia Aquifer, Maryland: evidence for an isotopically heavy source of $\mathrm{CO}_{2}$. Groundwater 23(5):592-599

Chapelle FH, Lovley DR (1992) Competitive exclusion of sulfate reduction by $\mathrm{Fe}(111)-r e d u c i n g$ bacteria: a mechanism for producing discrete zones of high-iron ground water. Groundwater 30(1):29-36

Charbonnier C, Anschutz P, Poirier D et al (2013) Aerobic respiration in a high-energy sandy beach. Mar Chem 155:10-21. https://doi. org/10.1016/j.marchem.2013.05.003

Charbonnier C, Lavesque N, Anschutz P et al (2016) Role of macrofauna on benthic oxygen consumption in sandy sediments of a highenergy tidal beach. Cont Shelf Res 120:96-105

Charette MA, Sholkovitz ER (2002) Oxidative precipitation of groundwater-derived ferrous iron in the subterranean estuary of a coastal bay. Geophys Res Lett 29(10):85-81

Charette MA, Sholkovitz ER, Hansel CM (2005) Trace element cycling in a subterranean estuary: Part 1. Geochemistry of the permeable sediments. Geochim Cosmochim Acta 69:2095-2109. https://doi. org/10.1016/j.gca.2004.10.024

Chipman L, Podgorski D, Green S et al (2010) Decomposition of plankton-derived dissolved organic matter in permeable coastal sediments. Limnol Oceanogr 55:857-871

Cho HM, Kim G, Kwon EY et al (2018) Radium tracing nutrient inputs through submarine groundwater discharge in the global ocean. Sci Rep 8:2439. https://doi.org/10.1038/s41598-018-20806-2

Coble PG (1996) Characterization of marine and terrestrial DOM in seawater using excitation-emission matrix spectroscopy. Mar Chem $51: 325-346$

Colbert SL, Berelson WM, Hammond DE (2008) Radon-222 budget in Catalina Harbor, California: 2. Flow dynamics and residence time in a tidal beach. Limnol Oceanogr 53:659-665

Couturier M, Nozais C, Chaillou G (2016) Microtidal subterranean estuaries as a source of fresh terrestrial dissolved organic matter to the coastal ocean. Mar Chem 186:46-57
Defeo O, McLachlan A, Schoeman DS et al (2009) Threats to sandy beach ecosystems: a review. Estuar Coast Shelf Sci 81(1):1-12

Deines P, Langmuir D, Harmon RS (1974) Stable carbon isotope ratios and the existence of a gas phase in the evolution of carbonate ground waters. Geochim Cosmochim Acta 38(7):1147-1164

Dimova NT, Swarzenski PW, Dulaiova H et al (2012) Utilizing multichannel electrical resistivity methods to examine the dynamics of the fresh water-seawater interface in two Hawaiian groundwater systems. J Geophys Res Ocean 117(C2):C02012

Drabbe J, Badon Ghijben W (1889) Nota in verband met de voorgenomen put-boring nabij Amsterdam (Notes on the results of the proposed well drilling in Amsterdam). Tijdschrift van het Koninklijk Instituut van Ingenieurs, Verhandelingen, Instituutjaar 1888/1889. pp 8-22

Ehlert C, Reckhardt A, Greskowiak J et al (2016) Transformation of silicon in a sandy beach ecosystem: Insights from stable silicon isotopes from fresh and saline groundwaters. Chem Geol 440:207218. https://doi.org/10.1016/j.chemgeo.2016.07.015

Fetter CW (1972) Position of the saline water interface beneath oceanic islands. Water Resour Res 8(5):1307-1315

Flemming BW, Davis RA Jr (1994) Holocene evolution, morphodynamics and sedimentology of the Spiekeroog barrier island system (southern North Sea). Senck Marit 24(1):117-155

Garcés E, Basterretxea G, Sánchez AT (2011) Changes in microbial communities in response to submarine groundwater input. Mar Ecol Prog Ser 438:47-58. https://doi.org/10.3354/meps09311

Goodridge BM, Melack JM (2014) Temporal evolution and variability of dissolved inorganic nitrogen in beach pore water revealed using radon residence times. Environ Sci Technol 48:14211-14218

Grünenbaum N, Greskowiak J, Harms A et al (2017) Investigation of the recirculation on the beach of Spiekeroog from in- to exfiltration. Poster presented at the European Geophysical Union (EGU) General Assembly 2017, Vienna, 23-28 April 2017

Hays RL, Ullman WJ (2007) Direct determination of total and fresh groundwater discharge and nutrient loads from a sandy beach face at low tide (Cape Henlopen, Delaware). Limnol Oceanogr 52(1):240-247

Heiss JW, Post VEA, Laattoe T et al (2017) Physical controls on biogeochemical processes in intertidal zones of beach aquifers. Water Resour Res 53:9225-9244

Herzberg A (1901) Die Wasserversorgung einiger Nordseebäder. J Gasbeleuchtung Wasserversorgung 44:815-819

Hild A (1997) Geochemie der Sedimente und Schwebstoffe im Rückseitenwatt von Spiekeroog und ihre Beeinflussung durch biologische Aktivität. Dissertation, Forschungszentrum Terramare, Wilhelmshaven, University Oldenburg

Hoehn E, Von Gunten HR (1989) Radon in groundwater: a tool to assess infiltration from surface waters to aquifers. Water Resour Res 25:1795-1803

Holguin G, Vazquez P, Bashan Y (2001) The role of sediment microorganisms in the productivity, conservation, and rehabilitation of mangrove ecosystems: an overview. Biol Fertil Soils 33:265-278. https://doi.org/10.1007/s003740000319

Holt T, Seibert SL, Greskowiak J et al (2017) Impact of storm tides and inundation frequency on water table salinity and vegetation on a juvenile barrier island. J Hydrol 554:666-679

Holt T, Greskowiak J, Seibert SL et al (2019) Modeling the evolution of a freshwater lens under highly dynamic conditions on a currently developing barrier island. Accepted by Geofluids

Houben GJ, Koeniger P, Sültenfuß J (2014) Freshwater lenses as archive of climate, groundwater recharge, and hydrochemical evo- 
lution: insights from depth-specific water isotope analysis and age determination on the island of Langeoog, Germany. Water Resour Res 50(10):8227-8239

Hu C, Muller-Karger FE, Swarzenski PW (2006) Hurricanes, submarine groundwater discharge, and floridas red tides. Geophys Res Lett 33(11):L11601

Huettel M, Ziebis W, Forster S et al (1998) Advective transport affecting metal and nutrient distributions and interfacial fluxes in permeable sediments. Geochim Cosmochim Acta 62:613-631

Jakobsen R, Postma D (1999) Redox zoning, rates of sulfate reduction and interactions with Fe-reduction and methanogenesis in a shallow sandy aquifer, Rømø, Denmark. Geochim Cosmochim Acta 63(1):137-151

Jeandel C, Oelkers EH (2015) The influence of terrigenous particulate material dissolution on ocean chemistry and global element cycles. Chem Geol 395:50-66

Jones A, Gladstone W, Hacking N (2007) Australian sandy-beach ecosystems and climate change: ecology and management. Aust Zool 34(2):190-202

Kim J, Kim G (2017) Inputs of humic fluorescent dissolved organic matter via submarine groundwater discharge to coastal waters off a volcanic island (Jeju, Korea). Sci Rep 7:7921. https://doi. org/10.1038/s41598-017-08518-5

Kim G, Ryu JW, Yang HS et al (2005) Submarine groundwater discharge (SGD) into the Yellow Sea revealed by Ra-228 and Ra-226 isotopes: implications for global silicate fluxes. Earth Planet Sci Lett 237:156-166

Kim TH, Waska H, Kwon E et al (2012) Production, degradation, and flux of dissolved organic matter in the subterranean estuary of a large tidal flat. Mar Chem 142-144:1-10

Kim TH, Kwon E, Kim I, Lee SA, Kim G (2013) Dissolved organic matter in the subterranean estuary of a volcanic island, Jeju: Importance of dissolved organic nitrogen fluxes to the ocean. J Sea Res 78:18-24

Kristensen E, Andersen FØ, Holmboe N et al (2000) Carbon and nitrogen mineralization in sediments of the Bangrong mangrove area, Phuket, Thailand. Aquat Microb Ecol 22:199-213

Kroeger KD, Charette MA (2008) Nitrogen biogeochemistry of submarine groundwater discharge. Limnol Oceanogr 53:1025-1039. https://doi.org/10.4319/lo.2008.53.3.1025

Kwon EY, Kim G, Primeau F et al (2014) Global estimate of submarine groundwater discharge based on an observationally constrained radium isotope model. Geophys Res Lett 41:62-68. https://doi. org/10.1002/2014GL061574

Lee DR (1977) A device for measuring seepage flux in lakes and estuaries. Limnol Oceanogr 22:140-147

Lee DR (1978) A field exercise on groundwater flow using seepage meter measurement of the flow using seepage meters and minipiezometers. J Geol Educ 27:6-20

Lee E, Shin D, Hyun SP et al (2016) Periodic change in coastal microbial community structure associated with submarine groundwater discharge and tidal fluctuation. Limnol Oceanogr 62:437-451. https://doi.org/10.1002/lno.10433

Li YH, Mathieu G, Biscaye P et al (1977) The flux of 226-Ra from estuarine and continental shelf sediments. Earth Planet Sci Lett $37: 237-241$

Linkhorst A, Dittmar T, Waska H (2017) Molecular fractionation of dissolved organic matter in a shallow subterranean estuary: the role of the iron curtain. Environ Sci Technol 51:1312-1320
Lipp JS, Morono Y, Inagaki F et al (2008) Significant contribution of Archaea to ex-tant biomass in marine subsurface sediments. Nature 454:991-994. https://doi.org/10.1038/nature07174

Liu J, Du J, Wu Y et al (2018) Nutrient input through submarine groundwater discharge in two major Chinese estuaries: the Pearl River Estuary and the Changjiang River Estuary. Estuar Coast Shelf Sci 203:17-28

Lovley DR, Phillips EJ (1987) Competitive mechanisms for inhibition of sulfate reduction and methane production in the zone of ferric iron reduction in sediments. Appl Environ Microbiol 53(11):2636-2641

Luijendijk A, Hagenaars G, Ranasinghe R et al (2018) The state of the world's beaches. Sci Rep 8(1):6641

Marsh Jr JA (1977) Terrestrial inputs of nitrogen and phosphorus on fringing reefs of Guam. In: Proceeding of the 2 nd international coral reef symposium, vol 1, pp 332-336

McAllister SM, Barnett JM, Heiss JW et al (2015) Dynamic hydrologic and biogeochemical processes drive microbially enhanced iron and sulfur cycling within the intertidal mixing zone of a beach aquifer. Limnol Oceanogr 60:329-345. https://doi.org/10.1111/lno.10029

McGranahan G, Balk D, Anderson B (2007) The rising tide: assessing the risks of climate change and human settlements in low elevation coastal zones. Environ Urban 19(1):17-37

McLachlan A (1983) Sandy beach ecology—a review. In: McLachlan A, Erasmus T (eds) Sandy beaches as ecosystems. Springer, Dordrecht, pp 321-380

Milliman JD, Müller G, Förstner F (2012) Recent sedimentary carbonates: part 1 marine carbonates. Springer, Berlin

Moore WS (1996) Large groundwater inputs to coastal waters revealed by Ra-226 enrichments. Nature 380:612-614

Moore WS (1999) The subterranean estuary: a reaction zone of ground water and sea water. Mar Chem 65(1-2):111-125

Moore WS (2000) Ages of continental shelf waters determined from 223Ra and 224Ra. J Geophys Res Ocean 105:22117-22122

Moore WS (2006) Radium isotopes as tracers of submarine groundwater discharge in Sicily. Cont Shelf Res 26:852-861

Moore WS (2010) The effect of submarine groundwater discharge on the ocean. Annu Rev Mar Sci 2:59-88

Mulligan AE, Charette MA (2006) Intercomparison of submarine groundwater discharge estimates from a sandy unconfined aquifer. J Hydrol 327:411-425

Nelson CE, Donahue MJ, Dulaiova H et al (2015) Fluorescent dissolved organic matter as a multivariate biogeochemical tracer of submarine groundwater discharge in coral reef ecosystems. Mar Chem 177:232-243

Nicholls RJ, Cazenave A (2010) Sea-level rise and its impact on coastal zones. Science 328(5985):1517-1520

O'Connor AE, Luek JL, McIntosh H et al (2015) Geochemistry of redox-sensitive trace elements in a shallow subterranean estuary. Mar Chem 172:70-81. https://doi.org/10.1016/j. marchem.2015.03.001

Osterholz H, Kirchman DL, Niggemann J et al (2016) Environmental drivers of dissolved organic matter molecular composition in the Delaware Estuary. Front Earth Sci 4:95. https://doi.org/10.3389/ feart.2016.00095

Paulsen RJ, Smith CF, O'Rourke D et al (2001) Development and evaluation of an ultrasonic ground water seepage meter. Groundwater 39(6):904-911

Peterson RN, Burnett WC, Taniguchi M et al (2008) Radon and radium isotope assessment of submarine groundwater discharge in the Yellow River delta. China J Geophys Res 113:C09021 
Post VEA (2005) Fresh and saline groundwater interaction in coastal aquifers: is our technology ready for the problems ahead? Hydrogeol J 13(1):120-123

Post VEA, Houben GJ (2017) Density-driven vertical transport of saltwater through the freshwater lens on the island of Baltrum (Germany) following the 1962 storm flood. J Hydrol 551:689-702

Postma D, Jakobsen R (1996) Redox zonation: equilibrium constraints on the $\mathrm{Fe}(\mathrm{III}) / \mathrm{SO}_{4}$-reduction interface. Geochim Cosmochim Acta 60(17):3169-3175

Reckhardt A, Beck M, Seidel M et al (2015) Carbon, nutrient and trace metal cycling in sandy sediments: a comparison of high-energy beaches and backbarrier tidal flats. Estuar Coast Shelf Sci 159:1-14. https://doi.org/10.1016/j.ecss.2015.03.025

Reckhardt A, Beck M, Greskowiak J et al (2017) Cycling of redoxsensitive elements in a sandy subterranean estuary of the southern North Sea. Mar Chem 188:6-17

Rickard D, Morse JW (2005) Acid volatile sulfide (AVS). Mar Chem 97(3):141-197

Riedel T, Lettmann K, Beck M et al (2010) Tidal variations in groundwater storage and associated discharge from an intertidal coastal aquifer. J Geophys Res 115:1-10

Robinson C, Li L, Barry D (2007) Effect of tidal forcing on a subterranean estuary. Adv Water Resour 30:851-865. https://doi. org/10.1016/j.advwatres.2006.07.006

Röper T, Kröger KF, Meyer H et al (2012) Groundwater ages, recharge conditions and hydrochemical evolution of a barrier island freshwater lens (Spiekeroog, Northern Germany). J Hydrol 454:173-186

Röper T, Greskowiak J, Freund H et al (2013) Freshwater lens formation below juvenile dunes on a barrier island (Spiekeroog, Northwest Germany). Estuar Coast Shelf Sci 121:40-50

Röper T, Greskowiak J, Massmann G (2015) Instabilities of submarine groundwater discharge under tidal forcing. Limnol Oceanogr 60(1):22-28

Rosenberry DO, Morin RH (2004) Use of an electromagnetic seepage meter to investigate temporal variability in Lake Seepage. Groundwater 42(1):68-77

Roy M, Martin JB, Smith CG et al (2011) Reactive-transport modeling of iron diagenesis and associated organic carbon remineralization in a Florida (USA) subterranean estuary. Earth Planet Sci Lett 304:191-201. https://doi.org/10.1016/j.epsl.2011.02.002

Santoro A (2009) Microbial nitrogen cycling at the saltwater-freshwater interface. Hydrogeol J 18:187-202. https://doi.org/10.1007/ s10040-009-0526-Z

Santoro AE, Francis CA, de Sieyes NR et al (2008) Shifts in the relative abundance of ammonia-oxidizing bacteria and archaea across physicochemical gradients in a subterranean estuary. Environ Microbiol 10(4):1068-1079. https://doi. org/10.1111/j.1462-2920.2007.01547.x

Santos IR, Burnett WC, Chanton J et al (2008) Nutrient biogeochemistry in a Gulf of Mexico subterranean estuary and groundwaterderived fluxes to the coastal ocean. Limnol Oceanogr 53:705-718. https://doi.org/10.4319/lo.2008.53.2.0705

Santos IR, Burnett WC, Dittmar T et al (2009) Tidal pumping drives nutrient and dissolved organic matter dynamics in a Gulf of Mexico subterranean estuary. Geochim Cosmochim Acta 73:1325-1339

Santos IR, Eyre BD, Huettel M (2012) The driving forces of porewater and groundwater flow in permeable coastal sediments: a review. Estuar Coastal Shelf Sci 98:1-15
Schoonen MA (2004) Mechanisms of sedimentary pyrite formation. Geol Soc Spec Pap 379:117-134

Seibert SL, Holt T, Reckhardt A et al (2018) Hydrochemical evolution of a freshwater lens below a barrier island (Spiekeroog, Germany): the role of carbonate mineral reactions, cation exchange and redox processes. Appl Geochem 92:196-208

Seibert SL, Böttcher ME, Schubert F et al (2019) Iron sulfide formation in young and rapidly-deposited permeable sands at the land-sea transition zone. Sci Total Environ 649:264-283

Seidel M, Beck M, Greskowiak J et al (2015) Benthic-pelagic coupling of nutrients and dissolved organic matter composition in an intertidal sandy beach. Mar Chem 176:150-163

Sirois M, Couturier M, Barber A et al (2018) Interactions between iron and organic carbon in a sandy beach subterranean estuary. Mar Chem 202:86-96

Slomp CP, Malschaert J (1997) Iron and manganese cycling in different sedimentary environments on the North Sea continental margin. Cont Shelf Res 17:1083-1117

Slomp CP, Van Cappellen P (2004) Nutrient inputs to the coastal ocean through submarine groundwater discharge: controls and potential impact. J Hydrol 295(1-4):64-86

Snow DD, Spalding RF (1997) Short-term aquifer residence times estimated from ${ }^{222} \mathrm{Rn}$ disequilibrium in artificially-recharged ground water. J Environ Radioact 37:307-325

Snyder M, Taillefert M, Ruppel C (2004) Redox zonation at the salineinfluenced boundaries of a permeable surficial aquifer: effects of physical forcing on the biogeochemical cycling of iron and manganese. J Hydrol 296(1):164-178

Spiteri C, Slomp CP, Charette MA et al (2008) Flow and nutrient dynamics in a subterranean estuary (Waquoit Bay, MA, USA): field data and reactive transport modeling. Geochim Cosmochim Acta 72(14):3398-3412

Stal LJ, Behrens SB, Villbrandt M et al (1996) The biogeochemistry of two eutrophic marine lagoons and its effect on microphytobenthic communities. Hydrobiologia 329:185-198. https://doi.org/10.1007/ BF00034557

Stieglitz T, Taniguchi M, Neylon S (2008) Spatial variability of submarine groundwater discharge, Ubatuba, Brazil. Estuar Coast Shelf Sci 76(3):493-500

Stuyfzand PJ (1993) Hydrochemistry and hydrology of the coastal dune area of the Western Netherlands. Dissertation, Vrije Universiteit of Amsterdam

Stuyfzand PJ (1998) Decalcification and acidification of coastal dune sands in the Netherlands. In: Arehart H (eds) Proceedings of the 9th international symposium on water-rock interaction, Taupo, New Zealand, pp 79-82

Stuyfzand PJ (1999) Patterns in groundwater chemistry resulting from groundwater flow. Hydrogeol J 7(1):15-27

Stuyfzand PJ (2017) Observations and analytical modeling of freshwater and rainwater lenses in coastal dune systems. J Coast Conserv 21(5):577-593

Suryaputra IG, Santos IR, Huettel M et al (2015) Non-conservative behavior of fluorescent dissolved organic matter (FDOM) within a subterranean estuary. Cont Shelf Res 110:183-190

Swarzenski PW (2007) U/Th series radionuclides as coastal groundwater tracers. Chem Rev 107:663-674

Swarzenski PW, Simonds FW, Paulson AJ et al (2007) Geochemical and geophysical examination of submarine groundwater discharge and associated nutrient loading estimates into Lynch Cove, Hood Canal, WA. Environ Sci Technol 41(20):7022-7029 
Tait DR, Erler DV, Santos IR et al (2014) The influence of groundwater inputs and age on nutrient dynamics in a coral reef lagoon. Mar Chem 166:36-47

Tamborski JJ, Cochran JK, Bokuniewicz HJ (2017) Application of ${ }^{224} \mathrm{Ra}$ and ${ }^{222} \mathrm{Rn}$ for evaluating seawater residence times in a tidal subterranean estuary. Mar Chem 189:32-45

United Nations Environment Programme (UNEP) (2014) The UNEP environmental data explorer, as compiled from UNEP/DEWA/ GRID-Geneva. UNEP, Geneva. http://geodata.grid.unep.ch

Vacher HL (1988) Dupuit-Ghyben-Herzberg analysis of strip-island lenses. Geol Soc Am Bull 100(4):580-591

Waldrop WR, Swarzenski PW (2006) A new tool for quantifying flux rates between surface water and ground water. In: Singh VP, Xu YJ (eds) Coastal hydrology and processes 24. Water Resources Publications, Highlands Ranch, pp 305-312
Werner AD, Simmons CT (2009) Impact of sea-level rise on sea water intrusion in coastal aquifers. Groundwater 47(2):197-204

Wilms R, Sass H, Köpke B et al (2007) Methane and sulfate profiles within the subsurface of a tidal flat are reflected by the distribution of sulfate-reducing bacteria and methanogenic archaea. FEMS Microbiol Ecol 59:611-621

Windom HL, Moore WS, Niencheski LFH et al (2006) Submarine groundwater discharge: a large, previously unrecognized source of dissolved iron to the South Atlantic Ocean. Mar Chem 102(3-4):252-266

Zark M, Christoffers J, Dittmar T (2017) Molecular properties of deepsea dissolved organic matter are predictable by the central limit theorem: evidence from tandem FT-ICR-MS. Mar Chem 191:9-15

Zhang J, Mandal AK (2012) Linkages between submarine groundwater systems and the environment. Curr Opin Environ Sustain 4:219-226

Open Access This chapter is licensed under the terms of the Creative Commons Attribution 4.0 International License (http://creativecommons. $\mathrm{org} /$ licenses/by/4.0/), which permits use, sharing, adaptation, distribution and reproduction in any medium or format, as long as you give appropriate credit to the original author(s) and the source, provide a link to the Creative Commons license and indicate if changes were made.

The images or other third party material in this chapter are included in the chapter's Creative Commons license, unless indicated otherwise in a credit line to the material. If material is not included in the chapter's Creative Commons license and your intended use is not permitted by statutory regulation or exceeds the permitted use, you will need to obtain permission directly from the copyright holder. 